\title{
Chloride Improves Nitrate Utilization and NUE in Plants
}

\author{
Miguel A. Rosales ${ }^{1,2 * t}$, Juan D. Franco-Navarro ${ }^{1,3+}$, Procopio Peinado-Torrubia ${ }^{1}$, \\ Pablo Díaz-Rueda ${ }^{1}$, Rosario Álvarez ${ }^{4}$ and José M. Colmenero-Flores ${ }^{1,2 *}$
}

${ }^{1}$ Grupo Regulación lónica e Hídrica en Plantas, Instituto de Recursos Naturales y Agrobiología, Consejo Superior de Investigaciones Cientificas (CSIC), Seville, Spain, ${ }^{2}$ Laboratorio Interdepartamental de Ecofisiología Molecular de Plantas, Instituto de Recursos Naturales y Agrobiología, Consejo Superior de Investigaciones Cientificas (CSIC), Seville, Spain, ${ }^{3}$ BioScripts - Centro de Investigación y Desarrollo de Recursos Científicos, Seville, Spain, ${ }^{4}$ Departamento de Biología Vegetal y Ecología, Facultad de Biología, Universidad de Sevilla, Seville, Spain

Chloride $\left(\mathrm{Cl}^{-}\right)$has traditionally been considered harmful to agriculture because of its toxic effects in saline soils and its antagonistic interaction with nitrate $\left(\mathrm{NO}_{3}{ }^{-}\right)$, which impairs $\mathrm{NO}_{3}{ }^{-}$nutrition. It has been largely believed that $\mathrm{Cl}^{-}$antagonizes $\mathrm{NO}_{3}{ }^{-}$ uptake and accumulation in higher plants, reducing crop yield. However, we have recently uncovered that $\mathrm{Cl}^{-}$has new beneficial macronutrient functions that improve plant growth, tissue water balance, plant water relations, photosynthetic performance, and water-use efficiency. The increased plant biomass indicates in turn that $\mathrm{Cl}^{-}$ may also improve nitrogen use efficiency (NUE). Considering that $N$ availability is a bottleneck for the growth of land plants excessive $\mathrm{NO}_{3}{ }^{-}$fertilization frequently used in agriculture becomes a major environmental concern worldwide, causing excessive leaf $\mathrm{NO}_{3}{ }^{-}$accumulation in crops such as vegetables, which poses a potential risk to human health. New farming practices aimed to enhance plant NUE by reducing $\mathrm{NO}_{3}{ }^{-}$fertilization should promote a healthier and more sustainable agriculture. Given the strong interaction between $\mathrm{Cl}^{-}$and $\mathrm{NO}_{3}{ }^{-}$homeostasis in plants, we have verified if indeed $\mathrm{Cl}^{-}$affects $\mathrm{NO}_{3}{ }^{-}$accumulation and NUE in plants. For the first time to our knowledge, we provide a direct demonstration which shows that $\mathrm{Cl}^{-}$, contrary to impairing $\mathrm{NO}_{3}{ }^{-}$nutrition, facilitates $\mathrm{NO}_{3}{ }^{-}$utilization and improves $\mathrm{NUE}$ in plants. This is largely due to $\mathrm{Cl}^{-}$improvement of the $\mathrm{N}^{-\mathrm{NO}_{3}}{ }^{-}$utilization efficiency $\left(\mathrm{NU}_{T} \mathrm{E}\right)$, having little or moderate effect on $\mathrm{N}-\mathrm{NO}_{3}{ }^{-}$uptake efficiency $\left(\mathrm{NU} U_{\mathrm{P}}\right.$ ) when $\mathrm{NO}_{3}{ }^{-}$is used as the sole $\mathrm{N}$ source. Clear positive correlations between leaf $\mathrm{Cl}^{-}$content vs. NUE/NUTE or plant growth have been established at both intra- and interspecies levels. Optimal $\mathrm{NO}_{3}{ }^{-}$vs. $\mathrm{Cl}^{-}$ratios become a useful tool to increase crop yield and quality, agricultural sustainability and to reduce the negative ecological impact of $\mathrm{NO}_{3}{ }^{-}$on the environment and on human health.

Keywords: chloride, nitrate, nitrogen use efficiency, crop yield, fertilizer, tobacco, leafy vegetables, nutritional quality

\section{INTRODUCTION}

Nitrogen $(\mathrm{N})$ is the main limiting nutrient for land plants and, therefore, has been classified as an essential macronutrient. Nitrate $\left(\mathrm{NO}_{3}{ }^{-}\right)$represents the major $\mathrm{N}$ source and a signal molecule involved in the control of many physiological and developmental processes, strongly improving crop yield (Frink et al., 1999; Wang et al., 2012; Krapp et al., 2014; Guan, 2017). The decisive role of $\mathrm{N}$ in crop yield has led to excessive use of $\mathrm{NO}_{3}{ }^{-}$in agriculture over decades 
generating serious environmental problems like water pollution, which is harmful to people and nature (Nitrates Directive, 1991; Kant et al., 2011). In addition, when the application rate of $\mathrm{NO}_{3}{ }^{-}$exceeds the plant growth needs, overaccumulation of $\mathrm{NO}_{3}{ }^{-}$in leaves reduces the nutritional quality of crops (Prasad and Chetty, 2008; Xing et al., 2019). Many large-leaved plants such as beets, cabbage, celery, lettuce, or spinach tend to store huge amounts of $\mathrm{NO}_{3}{ }^{-}$(MAFF, 1998), posing a serious risk to human health. When ingested, $\mathrm{NO}_{3}{ }^{-}$is rapidly converted to nitrite and $\mathrm{N}$-nitrous compounds as nitrosamines or nitric oxide causing methemoglobinemia or "blue baby syndrome" in infants and gastric cancer among other pathological disorders (Comly, 1945; Santamaria et al., 1999; Mensinga et al., 2003).

Considering that the growing world population is predicted to reach 9.8 billion in 2050, global efforts are being made to increase food resources by improving crop or agronomic practices (Tilman et al., 2002; Godfray et al., 2010). Since only $30-40 \%$ of the $\mathrm{N}$ applied to soil is used by plants, a greater $\mathrm{N}$ use efficiency (NUE) could improve the yield and quality of crops, reducing economic costs as well as decreasing environmental degradation (Baligar et al., 2001). NUE can be defined as the vegetative or reproductive biomass yield per unit of $\mathrm{N}$ available in the soil (Moll et al., 1982; Woodend and Glass, 1993; Ríos et al., 2010). This concept has many variants that can be split into two main elements: (i) $\mathrm{N}$ uptake efficiency $\left(\mathrm{NU}_{\mathrm{P}} \mathrm{E}\right)$, defined as the capacity of plant roots to take $\mathrm{N}$ from soil, and (ii) $\mathrm{N}$ utilization efficiency $\left(\mathrm{NU}_{\mathrm{T}} \mathrm{E}\right)$, defined as the fraction of plantacquired $\mathrm{N}$ to be converted to total biomass or grain yield (Xu et al., 2012). Both are considered important traits in agriculture to reduce the abusive use of $\mathrm{N}$ fertilizers or when low $\mathrm{N}$ availability constrains plant growth, with substantial benefits for farmers and to the environment (Baligar et al., 2001; Han et al., 2016). Crops with higher NUE promote greater yields under limited $\mathrm{N}$ in soil, or require lower $\mathrm{N}$ to produce the same yield as those with lower NUE capacity (Ruiz et al., 2006; Kant et al., 2011; Rubio-Wilhelmi et al., 2012). Therefore, when NUE is increased, both crop-production costs and the harmful input of $\mathrm{NO}_{3}{ }^{-}$into ecosystems are reduced.

Traditionally, chloride $\left(\mathrm{Cl}^{-}\right)$has been considered an essential micronutrient for plants (White and Broadley, 2001; Broadley et al., 2012). But recently, $\mathrm{Cl}^{-}$has been uncovered as beneficial when accumulated to macronutrient levels in plant tissues (Franco-Navarro et al., 2016; Raven, 2017; Wege et al., 2017; Colmenero-Flores et al., 2019), with new biological functions that improve tissue water balance, whole-plant water relations, photosynthesis performance, and water-use efficiency (FrancoNavarro et al., 2016, 2019; Nieves-Cordones et al., 2019). Chloride represents the dominant inorganic anion in the vacuole, with leaf contents that can be similar to those of the macronutrient $\mathrm{K}^{+}$, promoting cell osmoregulation, turgor-driven processes, leaf cell elongation, and a reduction in stomatal conductance ( $g_{\text {s }}$; Franco-Navarro et al., 2016). In addition, $\mathrm{Cl}^{-}$specifically increases mesophyll diffusion conductance to $\mathrm{CO}_{2}\left(g_{\mathrm{m}}\right)$ as a consequence of the greater surface area of chloroplasts exposed to the intercellular airspace of mesophyll cells, which in turn points towards $\mathrm{Cl}^{-}$playing a role in chloroplast performance (Franco-Navarro et al., 2019). Thus, $\mathrm{Cl}^{-}$specifically reduces $g_{s}$ and water loss through transpiration without affecting the photosynthetic capacity due to $g_{\mathrm{m}}$ stimulation, resulting in overall higher water-use efficiency (Franco-Navarro et al., 2016, 2019; Maron, 2019). Nitrate and $\mathrm{Cl}^{-}$are the most abundant inorganic anions, having similar physical and osmoregulatory properties and sharing transport mechanisms (Colmenero-Flores et al., 2019). This is probably the reason why $\mathrm{NO}_{3}^{-}$and $\mathrm{Cl}^{-}$ show strong dynamic interactions in plants (Wege et al., 2017), a phenomenon that has been described as a competitive interaction between these two monovalent anions. Different studies have reported a negative effect of $\mathrm{Cl}^{-}$on root $\mathrm{NO}_{3}^{-}$uptake and accumulation (Siddiqi et al., 1990; Cerezo et al., 1997; Xu et al., 2000). For this reason and because of the toxicity generated by excessive $\mathrm{Cl}^{-}$accumulation in sensitive crops under salt-stress conditions (Li et al., 2017; Geilfus, 2018), $\mathrm{Cl}^{-}$has been considered detrimental to agriculture. Overall, $\mathrm{Cl}^{-}$is believed to reduce NUE by limiting $\mathrm{NO}_{3}{ }^{-}$uptake and accumulation in plant tissues, reducing in turn its availability for plant metabolism (Xu et al., 2000; Anjana and Iqbal, 2007; Wege et al., 2017). However, $\mathrm{Cl}^{-}$ is a non-metabolized anion readily accumulated in plant tissues, whose vacuolar sequestration requires a lower energy cost than the accumulation of $\mathrm{NO}_{3}{ }^{-}$(Wege et al., 2017). Thus, considering the close interactions between these two anions, it has been hypothesized that preferential $\mathrm{Cl}^{-}$compartmentalization may reduce vacuolar $\mathrm{NO}_{3}{ }^{-}$storage in leaves (Flowers, 1988), allowing higher $\mathrm{NO}_{3}{ }^{-}$availability for plant metabolism and, consequently, promoting more efficient use of this $\mathrm{N}$ source, meaning higher NUE (Colmenero-Flores et al., 2019). Therefore, the goal of this study was to verify whether $\mathrm{Cl}^{-}$reduces leaf $\mathrm{NO}_{3}{ }^{-}$accumulation while promoting more efficient use of $\mathrm{N}-\mathrm{NO}_{3}{ }^{-}$. In order to prove this, different plant species with contrasting $\mathrm{Cl}^{-}$-accumulating abilities have been used in this work: three leafy herbaceous species with strong $\mathrm{Cl}^{-}$-including capacity (chard, spinach, and lettuce), two herbaceous $\mathrm{Cl}^{-}$-including Solanaceae species (tobacco and tomato), and two $\mathrm{Cl}^{-}$-excluding woody species (olive and the salt-tolerant citrus rootstock Cleopatra mandarin). To directly ascertain the effect of $\mathrm{Cl}^{-}$on $\mathrm{NO}_{3}{ }^{-}$nutrition, plant growth and different NUE parameters have been quantified, using $\mathrm{NO}_{3}{ }^{-}$as the sole $\mathrm{N}$ source.

\section{MATERIALS AND METHODS}

\section{Plant Species and Nutritional Treatments}

Tobacco (Nicotiana tabacum L. var. habana) plants were grown under experimental greenhouse conditions at $25 \pm 3^{\circ} \mathrm{C} / 17 \pm 2{ }^{\circ} \mathrm{C}$ (day/night), relative humidity of $60 \pm 10 \%$ (EL-1-USB Datalogger, Lascar Electronics Inc., Erie, PA, United States), a $14 \mathrm{~h} / 10 \mathrm{~h}$ photoperiod with a photosynthetic photon flux density [average photosynthetically active radiation (PAR)] of 300-350 $\mu \mathrm{mol} \mathrm{m} \mathrm{m}^{-2} \mathrm{~s}^{-1}$ (quantum sensor, LI-6400; Li-COR, Lincoln, NE, United States), and a luminous emittance of 9,00010,000 lx (Digital Lux Meter, LX1010B; Carson Electronics, Valemount, Canada). Seeds were sown in flat trays (cell size, $4 \mathrm{~cm} \times 4 \mathrm{~cm} \times 10 \mathrm{~cm}$ ) containing peat previously washed with the corresponding nutrient solutions. After 2 days of vernalization in a cold chamber $\left(4^{\circ} \mathrm{C}\right)$, seedbeds were 
transferred to a greenhouse. 21 days after sowing (DAS), seedlings were transplanted to $7.5 \mathrm{~L}$ pots (with a pot size of $20 \mathrm{~cm} \times 17 \mathrm{~cm} \times 25 \mathrm{~cm}$ ) that contained a mix of perlite/vermiculite (4:6). Plants were watered with a basal nutrient solution supplemented with three salt solutions containing the same cationic balance: $5 \mathrm{mM} \mathrm{Cl}^{-}$-based treatment (CL; with $5.075 \mathrm{mM} \mathrm{Cl}^{-}$and $5.25 \mathrm{mM} \mathrm{NO}_{3}^{-}$), $5 \mathrm{mM} \mathrm{NO}_{3}^{-}$based treatment $\left(\mathrm{N}\right.$; with $75 \mu \mathrm{M} \mathrm{Cl}^{-}$and $10.25 \mathrm{mM} \mathrm{NO}_{3}{ }^{-}$) and sulfate + phosphate $\left(\mathrm{SO}_{4}{ }^{2-}+\mathrm{PO}_{4}{ }^{3-}\right)$-based treatment (SP; with $75 \mathrm{\mu M} \mathrm{Cl}^{-}$and $5.25 \mathrm{mM} \mathrm{NO}_{3}{ }^{-}$). The composition of the basal solution (BS) was as follows: $1.25 \mathrm{mM} \mathrm{KNO}_{3}, 0.725 \mathrm{mM}$ $\mathrm{KH}_{2} \mathrm{PO}_{4}, 0.073 \mathrm{mM} \mathrm{K}_{2} \mathrm{HPO}_{4}, 2 \mathrm{mM} \mathrm{Ca}\left(\mathrm{NO}_{3}\right)_{2}, 1 \mathrm{mM} \mathrm{MgSO}$, $0.1 \mathrm{mM}$ FeNa-ethylenediaminetetraacetic acid (EDTA), $0.1 \mathrm{mM}$ $\mathrm{H}_{3} \mathrm{BO}_{3}, 0.1 \mathrm{mM} \mathrm{MnSO}_{4}, 29 \mu \mathrm{M} \mathrm{ZnSO}_{4}, 0.1 \mu \mathrm{M} \mathrm{CuSO}_{4}, 1 \mu \mathrm{M}$ $\mathrm{Na}_{2} \mathrm{MoO}_{4}$, and $5 \mu \mathrm{M}$ KI. A detailed description of the nutritional treatments is given in the Supplementary Table S1. Considering that $50 \mu \mathrm{M} \mathrm{Cl}^{-}$was reported to ensure $\mathrm{Cl}^{-}$micronutrient requirements in different plant species (Johnson et al., 1957),

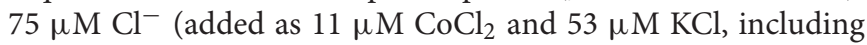
water traces) was present in the basal nutrient solution to fulfill micronutrient $\mathrm{Cl}^{-}$functions in low $\mathrm{Cl}^{-}$treatments (FrancoNavarro et al., 2016, 2019). In these previous works, we showed that the SP supplement did not modify the parameters analyzed with respect to the baseline treatment (BS). For this reason, and because the SP treatment only modifies the anionic content with respect to the CL treatment (while the BS solution differs in both anionic and cationic content), the BS treatment was not included in this work. Furthermore, previous experiments showed no significant differences in NUE parameters between BS and SP treatments (results not shown). A second set of experiments with increasing concentrations of anions was used in CL treatments: $0 \mathrm{mM} \mathrm{Cl}^{-}$(basal solution containing $0.075 \mathrm{mM} \mathrm{Cl}^{-}$), $0.151 \mathrm{mM}$ $\mathrm{Cl}^{-}, 0.301 \mathrm{mM} \mathrm{Cl}^{-}, 1.075 \mathrm{mM} \mathrm{Cl}^{-}, 2.575 \mathrm{mM} \mathrm{Cl}^{-}$, and $5.075 \mathrm{mM} \mathrm{Cl}^{-}$. As a control condition, equivalent SP treatments were used to ensure similar cationic balance as in the different CL treatments (Supplementary Table S1). All experimental solutions were adjusted to $\mathrm{pH} 5.7$ with $\mathrm{KOH}$. Pots were irrigated up to field capacity $\left(3.5 \mathrm{~mL} \mathrm{~g}^{-1}\right.$ substrate) along with the experiments. Tobacco plants were harvested at 64 DAS, and different plant tissues were preserved for subsequent analyses.

To find out the ratio of $\mathrm{Cl}^{-}$vs. $\mathrm{NO}_{3}{ }^{-}$that promotes more efficient use of $\mathrm{N}$, tobacco plants were subjected to varying ratios of $\mathrm{Cl}^{-}, \mathrm{NO}_{3}^{-}$, and $\mathrm{SO}_{4}{ }^{2-}+\mathrm{PO}_{4}{ }^{3-}$ as follows (Supplementary Table S2): (i) constant $8 \mathrm{mM} \mathrm{NO}_{3}{ }^{-}$ combined with increasing $\mathrm{Cl}^{-}$concentrations and decreasing $\mathrm{SO}_{4}{ }^{2-}+\mathrm{PO}_{4}{ }^{3-}$ concentrations $\left(\mathrm{mM} ; \mathrm{NO}_{3}{ }^{-} / \mathrm{SO}_{4}{ }^{2-}+\mathrm{PO}_{4}{ }^{3-}\right.$ : 0.075:8, 0.575:7.5, 2.075:6, 4.075:4, and 6.075:2) and (ii) constant $6.075 \mathrm{mM} \mathrm{Cl}^{-}$combined with increasing $\mathrm{SO}_{4}{ }^{2-}+\mathrm{PO}_{4}{ }^{3-}$ concentrations and decreasing $\mathrm{NO}_{3}{ }^{-}$concentrations (mM; $\left.\mathrm{Cl}^{-} / \mathrm{SO}_{4}{ }^{2-}+\mathrm{PO}_{4}{ }^{3-}: 6: 4,4: 6\right)$. The minimum content of $\mathrm{Cl}^{-}$ was maintained at $75 \mu \mathrm{M}$ to ensure the minimal micronutrient requirement (Franco-Navarro et al., 2016), which was estimated up to $50 \mu \mathrm{M}$ in the nutrient solution as reported in Johnson et al. (1957) and Whitehead (1985), and salt combinations contained the same cationic balance.

SP and CL treatments $(5 \mathrm{mM})$ were applied at 21 DAS under similar experimental conditions (as described above) in: (i) woody species like olive (Olea europaea L. ssp. europaea var. sylvestris Brot.) and the citrus rootstock Cleopatra mandarin (Citrus reshni Hort. ex Tan.); and (ii) herbaceous species like cherry tomato (Solanum lycopersicum L. cv zarina), Taglio chard (Beta vulgaris L. ssp. vulgaris convar. cicla var. flavescens Dc.), America spinach (Spinacia oleracea L. var. america), and lettuce romaine (Lactuca sativa ssp. longifolia Lam.). For olive plants, in vitro germination of zygotic embryos was required. Seeds were sterilized and germinated under sterile conditions in tubes containing $10 \mathrm{~mL}$ of olive culture medium (Rugini, 1984) supplemented with $1 \mathrm{mg} \mathrm{L}^{-1}$ zeatin, $20 \mathrm{~g} \mathrm{~L}^{-1}$ mannitol, and $6 \mathrm{~g} \mathrm{~L}^{-1}$ agar. Medium $\mathrm{pH}$ was adjusted to 5.7 before autoclaving at $121^{\circ} \mathrm{C}$ for $20 \mathrm{~min}$. After placing the embryos in the agar medium, they were incubated in the growth chamber for 60 days. Growing conditions were $23 \pm 2^{\circ} \mathrm{C}, 16 \mathrm{~h}$ light $/ 8 \mathrm{~h}$ dark photoperiod, and 70\%/30\% Red/Blue with a photosynthetic photon flux (PPF) of $34 \mu \mathrm{E}$. Seedlings were placed in rooting medium for 21 days before being acclimatized in pots for 21 days and then harvested at 200 DAS. The other plant species were harvested at different times as follows: at 67 DAS in tomato, 84 DAS in mandarin, 106 DAS in spinach, and 147 DAS in chard and lettuce.

Plant samples harvested in all experiments were dried in a forced-air oven at $75^{\circ} \mathrm{C}$ to obtain the dry weight (DW) and dry preserved for subsequent determinations. All experiments were performed in at least three independent trials.

\section{Nutrient Content and NUE Parameters}

For the determination of nutrient content, fully photosynthetic and expanded mature leaves (non-senescent) were used. Ovendried leaf tissue was ground into powder using a grinder, and the concentration of $\mathrm{Cl}^{-}, \mathrm{NO}_{3}{ }^{-}, \mathrm{SO}_{4}{ }^{2-}$, and $\mathrm{PO}_{4}{ }^{3-}$ was determined as previously reported in Franco-Navarro et al. (2016). $\mathrm{NH}_{4}{ }^{+}$was determined from an aqueous extraction by using the colorimetric method described by Krom (1980), and was measured with the absorbance microplate reader "Omega SPECTROstar" (BMG LABTECH GmbH, Germany). Organic N was determined by the Kjeldahl method (Bradstreet, 1954). Total N content (TNC) was expressed as $\mathrm{mg} \mathrm{g}^{-1} \mathrm{DW}$ and represents the sum of organic $\mathrm{N}, \mathrm{NH}_{4}{ }^{+}$, and $\mathrm{NO}_{3}{ }^{-}$(Ríos et al., 2010). Total $\mathrm{N}$ accumulation (TNA) was calculated as the result of TNC divided by total DW as described in Sorgona et al. (2006), and results were expressed as $\mathrm{mg}$ of $\mathrm{N}$. NUE is commonly defined as vegetative yield per unit of $\mathrm{N}$ available to the crop ( $\mathrm{g}$ DW $\mathrm{g}^{-1} \mathrm{~N}$; Moll et al., 1982; Woodend and Glass, 1993; Rubio-Wilhelmi et al., 2012) and can be subdivided into two types: (i) $\mathrm{N}$ utilization efficiency $\left(\mathrm{NU}_{\mathrm{T}} \mathrm{E}\right)$ calculated as total DW divided by TNC $\left(\mathrm{g}^{2} \mathrm{DW} \mathrm{mg}^{-1} \mathrm{~N}\right.$; Siddiqi and Glass, 1981) and (ii) $\mathrm{N}$ uptake efficiency ( $\left.\mathrm{NU}_{\mathrm{P}} \mathrm{E}\right)$ calculated as TNA divided by root $\mathrm{DW}\left(\mathrm{mg} \mathrm{N} \mathrm{g}^{-1}\right.$ root $\mathrm{DW}$; Elliott and Læuchli, 1985).

\section{Statistical Analysis}

Statistical analysis was performed using the STATGRAPHICS Centurion XVI software (StatPoint Technologies, Warrenton, VA, United States). The Shapiro-Wilk $(W)$ test was used to verify the normality of the datasets. Both one-way analysis of variance (ANOVA) and multivariate analysis of variance 
(MANOVA) were done to determine significant differences between groups of samples, and levels of significance were described by asterisks: $P \leq 0.05\left(^{*}\right), P \leq 0.01\left(^{* *}\right)$, and $P \leq 0.001\left(^{* * *}\right)$. No significant (NS) differences were indicated when $P>0.05$. Multiple comparisons of means were determined by the Tukey's honestly significant difference (HSD) and multiple range test (MRT) tests included in the afore-mentioned software. Correlations between NUE parameters and $\mathrm{Cl}^{-}$concentrations were calculated through Pearson's product-moment correlation coefficient $\left(r^{2}\right)$. Values represent the mean of at least five tobacco plants in each treatment, which were reproducible in at least two independent experiments.

\section{RESULTS}

\section{Effect of $\mathrm{Cl}^{-}$on Leaf Ion Content, Growth, and NUE Parameters in Tobacco Plants}

The three nutritional treatments assayed (SP, N, and CL) showed leaf ionic contents consistent with the nutritional supplements applied (Supplementary Table S3). Thus, CL plants accumulated $\mathrm{Cl}^{-}$at levels that are typical of a macronutrient such as $\mathrm{K}^{+}$ (55.1 $\mathrm{mg} \mathrm{Cl}^{-} \mathrm{g}^{-1} \mathrm{DW}$ and $49.5 \mathrm{mg} \mathrm{K}^{+} \mathrm{g}^{-1} \mathrm{DW}$, respectively). Leaf $\mathrm{Cl}^{-}$content in CL plants was higher than the contents of $\mathrm{NO}_{3}{ }^{-}$and $\mathrm{SO}_{4}{ }^{2-}+\mathrm{PO}_{4}{ }^{3-}$ in $\mathrm{N}$ and SP plants, respectively (Supplementary Table S3). It is important to notice that the leaf $\mathrm{Cl}^{-}$content in tobacco plants treated with low $\mathrm{Cl}^{-}$levels (SP and $\mathrm{N}$ treatments) exceeded the critical deficiency threshold reported for $\mathrm{Cl}^{-}$in non-halophytic plants $\left(<0.2 \mathrm{mg} \mathrm{g}^{-1}\right.$ shoot DW; Flowers, 1988; Xu et al., 2000; White and Broadley, 2001). Therefore, $\mathrm{N}$ and SP treatments satisfied plant $\mathrm{Cl}^{-}$ requirements as essential micronutrient, and no symptoms of $\mathrm{Cl}^{-}$deficiency like wilting, chlorosis, bronzing, or necrosis were observed. As a demonstration of this fact, we noted that $\mathrm{N}$ plants, containing low $\mathrm{Cl}^{-}$content, exhibited the highest plant growth (Franco-Navarro et al., 2016; Figure 1A). As previously observed, $\mathrm{Cl}^{-}$supplementation stimulated plant growth (when compared to the SP treatment) (Figures 1A, 2A). Interestingly, the beneficial effect of $\mathrm{Cl}^{-}$nutrition on plant dry biomass was only evident in response to treatments higher than $1 \mathrm{~m} \mathrm{M} \mathrm{Cl}^{-}$, within the macronutrient-content range (Figure 2A). Therefore, these results show that $\mathrm{Cl}^{-}$stimulates plant growth when it is supplied at macronutrient levels and ruled out the occurrence of $\mathrm{Cl}^{-}$deficiency in plants subjected to low $\mathrm{Cl}^{-}$treatments (SP and $\mathrm{N}$ treatments).

In tobacco plants, the $\mathrm{N}$ treatment $\left(10.25 \mathrm{mM} \mathrm{NO}_{3}{ }^{-}\right)$ duplicated the $\mathrm{NO}_{3}{ }^{-}$concentration in comparison with SP and CL treatments $\left(5.25 \mathrm{mM} \mathrm{NO}_{3}{ }^{-}\right)$, resulting in strong stimulation of plant growth (Supplementary Table S1 and Figure 1A) and confirming the well-known fact that $\mathrm{N}$ availability bottlenecks plant growth (Glass, 2003; Hawkesford et al., 2012; Wang et al., 2012; Krapp et al., 2014; Guan, 2017). However, the most efficient use of $\mathrm{N}$ occurred in CL plants, which showed the highest NUE values (Figure 1B) despite presenting the lowest $\mathrm{NO}_{3}{ }^{-}$content (Supplementary Table S3). NUE defines the total biomass production per unit of $\left.\mathrm{N}_{\left(\mathrm{NO}_{3}\right.}^{-}\right)$available in the soil (Moll et al., 1982). Two different components of NUE can be in turn distinguished: (i) how efficiently is this nutrient transported into the plant, defined by the $\mathrm{N}$ uptake efficiency $\left(\mathrm{NU}_{\mathrm{P}} \mathrm{E}\right)$, and (ii) how efficiently the transported $\mathrm{N}$ is used by the plant, defined by the $\mathrm{N}$ utilization efficiency $\left(\mathrm{NU}_{\mathrm{T}} \mathrm{E}\right)$, which takes into account the plant yield component (Siddiqi and Glass, 1981). As a result of the greater $\mathrm{NO}_{3}{ }^{-}$availability, the $\mathrm{N}$ treatment resulted in a strong increase in $\mathrm{NU}_{\mathrm{P}} \mathrm{E}$ (Figure 1C), giving rise to higher TNC (Figure 1D) and TNA (Figure 1E) in comparison to the SP and CL treatments. However, such high tissue content of $\mathrm{N}$ determined the lowest $\mathrm{NU}_{\mathrm{T}} \mathrm{E}$ value in $\mathrm{N}$ plants (Figure 1E), which was $70 \%$ lower than that of CL plants. Interestingly, while both $\mathrm{CL}$ and SP treatments contained the same $\mathrm{NO}_{3}{ }^{-}$ concentration, the $\mathrm{CL}$ treatment determined $41 \%$ higher $\mathrm{NU}_{\mathrm{T}} \mathrm{E}$ than the SP treatment.

To better define the interaction between $\mathrm{Cl}^{-}$and NUE, the plant response to increasing $\mathrm{Cl}^{-}$concentrations was compared to equivalent gradients of $\mathrm{SO}_{4}{ }^{2-}+\mathrm{PO}_{4}{ }^{3-}$ concentrations. A clear positive response to $\mathrm{Cl}^{-}$treatments was observed beyond $1 \mathrm{mM} \mathrm{Cl}^{-}$, significantly improving plant growth (Figure 2A) and NUE (Figure 2B) in comparison to SP treatments. These CL treatments determined leaf tissue contents of about $40-110 \mathrm{mM}$ $\mathrm{Cl}^{-}$, confirming the beneficial effect of $\mathrm{Cl}^{-}$at macronutrient levels. Interestingly, no significant differences were observed in the $\mathrm{NU}_{\mathrm{P}} \mathrm{E}$ between the CL and SP treatments (both containing the same concentration of $5.25 \mathrm{mM} \mathrm{NO}_{3}{ }^{-}$; Figure 2C), whereas $\mathrm{NU}_{\mathrm{T}} \mathrm{E}$ values were higher in $\mathrm{CL}$ plants subjected to treatments $\geq 1 \mathrm{mM} \mathrm{Cl}^{-}$(Figure 2D). This confirmed that the NUE component improved by $\mathrm{Cl}^{-}$is the utilization rather than the uptake efficiency of $\mathrm{NO}_{3}{ }^{-}$. Thus, a positive and statistically significant correlation between $\mathrm{NU}_{\mathrm{T}} \mathrm{E}$ and leaf $\mathrm{Cl}^{-}$content was confirmed $\left(r^{2}=0.99\right.$; Figure 2F), which could not be established with the $\mathrm{NU}_{\mathrm{P}} \mathrm{E}$ (Figure 2E) in tobacco plants.

\section{Effect of Different $\mathrm{Cl}^{-} / \mathrm{NO}_{3}{ }^{-}$and $\mathrm{Cl}^{-} / \mathrm{SO}_{4}{ }^{2-}+\mathrm{PO}_{4}{ }^{3-}$ Ratios on Anion Content, Growth, and NUE Parameters of Tobacco Plants}

To better understand whether $\mathrm{Cl}^{-}$has a direct antagonistic effect on $\mathrm{NO}_{3}{ }^{-}$nutrition, and therefore on plant performance, tobacco plants treated with the same $\mathrm{NO}_{3}{ }^{-}$concentration $(8 \mathrm{mM}$ $\mathrm{NO}_{3}{ }^{-}$) were supplemented with growing $\mathrm{Cl}^{-}$concentrations ( 0 , $0.5,2,4$, and $6 \mathrm{mM} \mathrm{Cl}^{-}$). To maintain a similar cationic and osmotic balance in all treatments, $\mathrm{Cl}^{-}$salts were compensated with $\mathrm{SO}_{4}{ }^{2-}+\mathrm{PO}_{4}{ }^{3-}$ salts according to the experimental design presented in Supplementary Table S2. Increasing $\mathrm{Cl}^{-}$ concentrations gave rise to increasing leaf $\mathrm{Cl}^{-}$contents, which in turn produced significant reductions in $\mathrm{NO}_{3}{ }^{-}$content in the 4 and $6 \mathrm{mM} \mathrm{Cl}^{-}$treatments $(53$ and $71 \%$ reduction in $\mathrm{NO}_{3}{ }^{-}$content, respectively; Figure 3A). Interestingly, these strong reductions in leaf $\mathrm{NO}_{3}^{-}$content did not result in a worsening of plant performance, and contrary to what is traditionally belief, $\mathrm{Cl}^{-}$treatments significantly increased plant biomass (Figure 3B) and NUE (Figure 3C). The results clearly suggest that a reduction in $\mathrm{NO}_{3}^{-}$content by $\mathrm{Cl}^{-}$application 

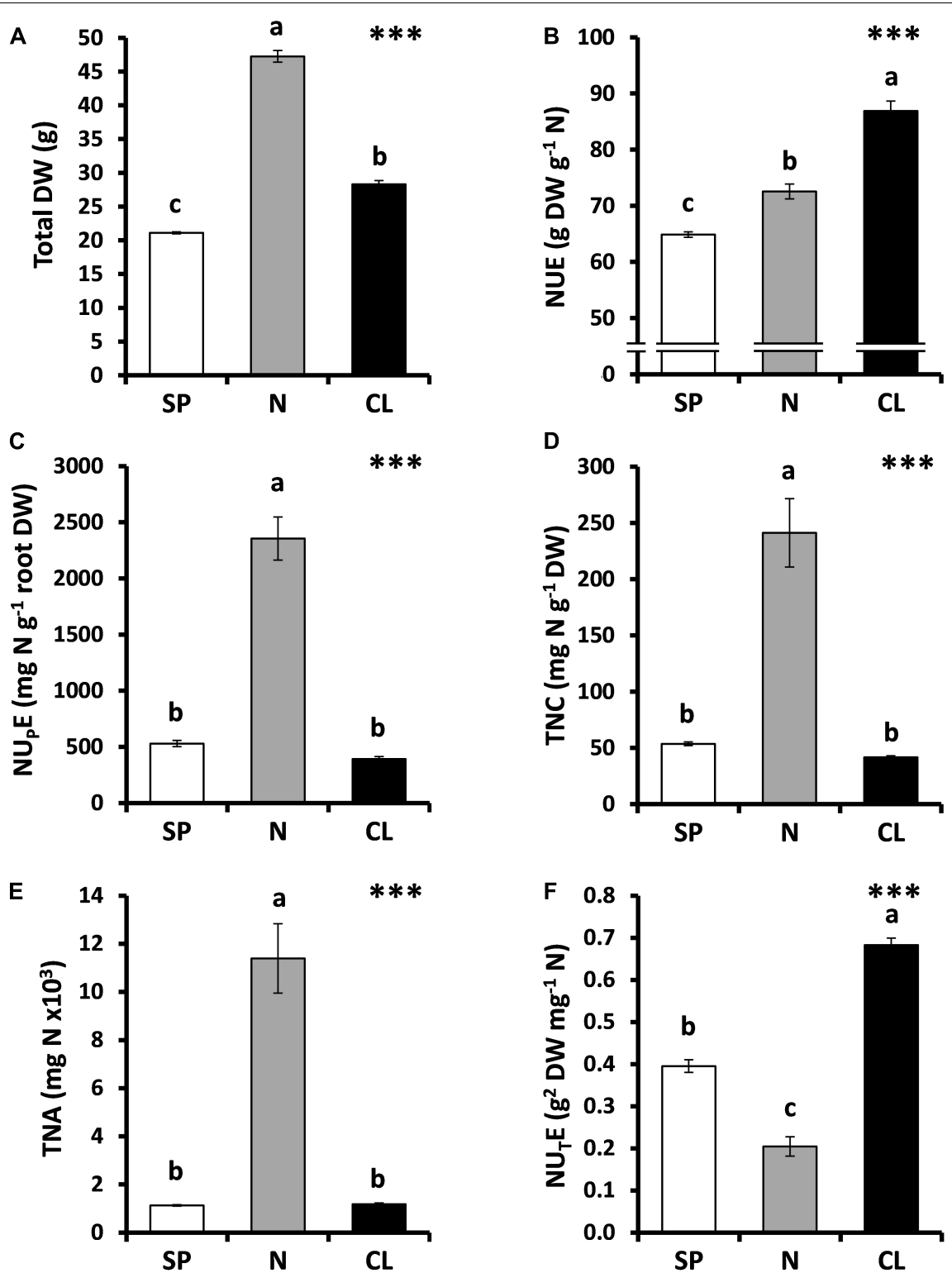

FIGURE 1 | Effect of $\mathrm{Cl}^{-}$nutrition on tobacco biomass and nitrogen use efficiency (NUE) parameters. Treatments consisted of the application of the basal nutrient solution supplemented with $5 \mathrm{mM} \mathrm{Cl}^{-}(\mathrm{CL}), 5 \mathrm{mM} \mathrm{NO}_{3}{ }^{-}(\mathrm{N})$, or the $\mathrm{SO}_{4}{ }^{2-}+\mathrm{PO}_{4}{ }^{3-}(\mathrm{SP})$ salt mixture, containing the same cationic balance in all treatments. (A) Total dry weight (DW). (B) NUE. (C) Nitrogen-uptake efficiency (NUPE). (D) Total nitrogen content (TNC). (E) Total nitrogen assimilated (TNA). (F) Nitrogen-utilization efficiency (NUTE). Mean values $\pm \mathrm{SE}, n=4-6$. Levels of significance: *** $P \leq 0.001$; and "homogeneous group" statistics was calculated through ANOVA tests, where mean values with different letters are significantly different according toTukey's test.

is not due to a reduction in $\mathrm{NO}_{3}^{-}$availability within the plant but to a greater $\mathrm{NO}_{3}{ }^{-}$assimilation, which results in increased NUE and plant biomass. Additionally, we applied decreasing $\mathrm{NO}_{3}{ }^{-}$treatments (from 8 to 6 and $4 \mathrm{mM} \mathrm{NO}_{3}{ }^{-}$) while maintaining the $6 \mathrm{mM} \mathrm{Cl}^{-}$treatment (by replacing $\mathrm{NO}_{3}{ }^{-}$by equivalent concentrations of $\mathrm{SO}_{4}{ }^{2-}+\mathrm{PO}_{4}{ }^{3-}$ salts). Although leaf $\mathrm{NO}_{3}{ }^{-}$contents were only slightly reduced after reducing 25 and $50 \%$ the $\mathrm{NO}_{3}{ }^{-}$concentration in the nutrient solution, total plant biomass strongly dropped up to $45 \%$ of the dry weight, coinciding with a slight reduction in NUE (Figures 3D-F). This is a consequence of the lower availability of $\mathrm{NO}_{3}{ }^{-}$for the plant, causing a strong reduction in plant biomass.

\section{Effect of $\mathrm{Cl}^{-}$on NUE Parameters in Different Plant Species}

Considering these results, we hypothesized that a positive interaction between $\mathrm{Cl}^{-}$nutrition and NUE is a widespread phenomenon in land plants. In order to answer this important question, herbaceous and woody plant species from different families with contrasting capacities to transport and accumulate $\mathrm{Cl}^{-}$were tested in response to the $5 \mathrm{mM} \mathrm{Cl}^{-}$treatment (Table 1 ). 

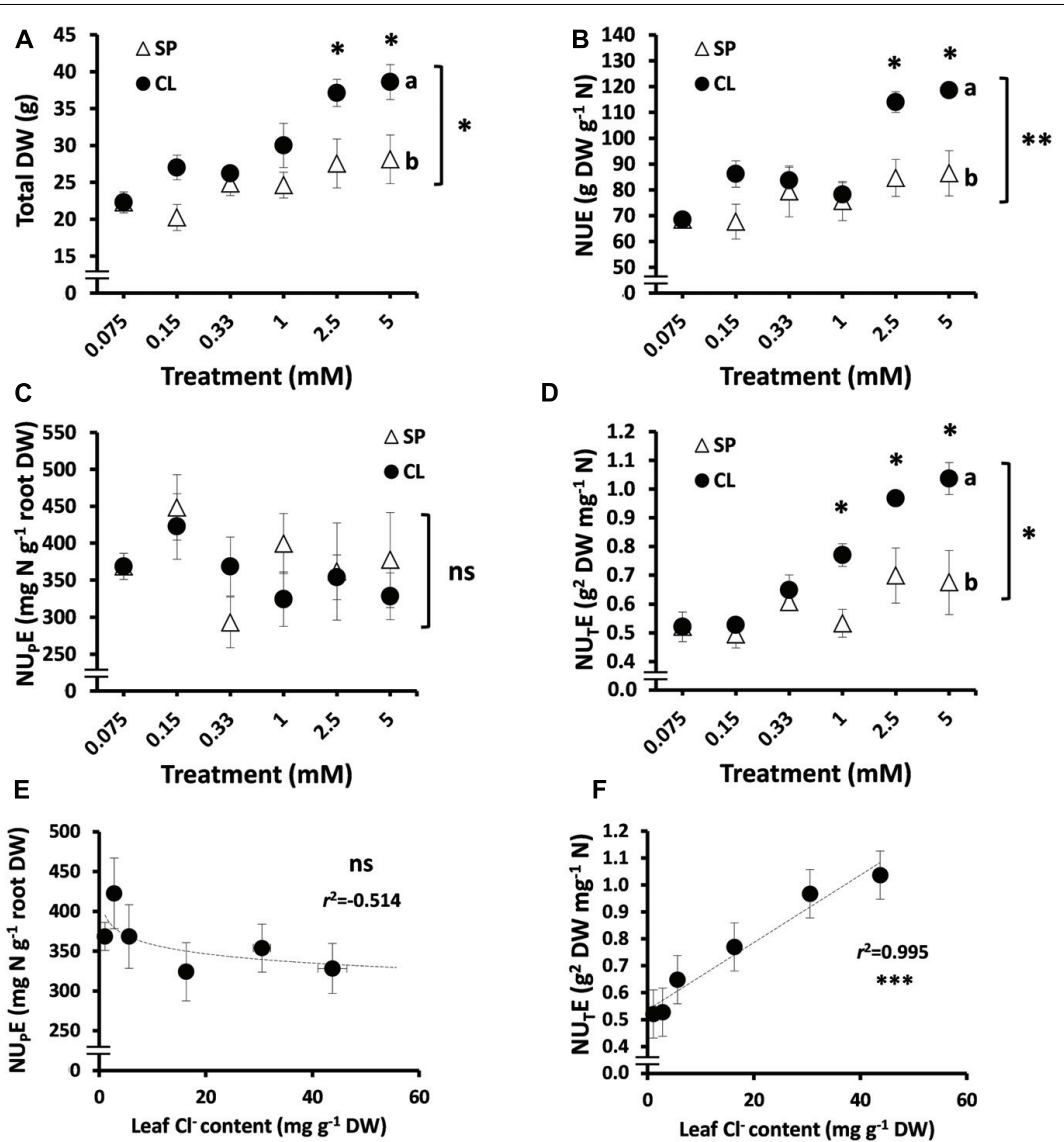

FIGURE 2 | Effect of $\mathrm{Cl}^{-}$nutrition on tobacco plant biomass and nitrogen use efficiency (NUE) parameters. Treatments consisted of increasing concentrations of $\mathrm{Cl}^{-}$ (CL) or $\mathrm{SO}_{4}{ }^{2-}+\mathrm{PO}_{4}{ }^{3-}$ (SP) salts maintaining the same cationic balance. (A) Effect on total dry weight (DW). (B) NUE. (C) Nitrogen-uptake efficiency (NUpE). (D) Nitrogen-utilization efficiency $\left(\mathrm{NU} U_{T} \mathrm{E}\right)$; $(\mathbf{E})$ Pearson correlation $\left(r^{2}\right)$ between $\mathrm{NU}_{\mathrm{P}}$ E and leaf anion content in tobacco plants. (F) Pearson correlation $\left(r^{2}\right)$ between $\mathrm{NU}_{\mathrm{T}} \mathrm{E}$ and leaf anion content in tobacco plants. Mean values $\pm \mathrm{SE}, n=4-6$. Levels of significance: $P>0.05$ (ns, not significant), ${ }^{*} P \leq 0.05,{ }^{* *} P \leq 0.01$, and ${ }^{* * *} P \leq 0.001$; and "homogeneous group" statistics was calculated through ANOVA and multivariate (MANOVA) tests, where mean values with different letters are significantly different according toTukey's test. Correlations between $\mathrm{NU} U_{T} \mathrm{E}$ or $\mathrm{NU} \mathrm{P}_{\mathrm{P}}$ and leaf anion content were calculated through the Pearson's product-moment correlation coefficient $\left(r^{2}\right)$.

This study included several herbaceous and woody species of agricultural interest: leafy vegetables with strong $\mathrm{Cl}^{-}$-including capacity from the Amaranthaceae (chard) and the Asteraceae (lettuce) families; $\mathrm{Cl}^{-}$-including species from the Solanaceae family (tobacco and tomato); and two $\mathrm{Cl}^{-}$-excluding woody perennial species from the Oleaceae (olive) and the Rutaceae families (the salt-tolerant citrus rootstock Cleopatra mandarin; Brumós et al., 2010).

When treated with $5 \mathrm{mM} \mathrm{Cl}^{-}$, the $\mathrm{Cl}^{-}$-excluding species O. europaea and Cleopatra mandarin accumulated 7.36 and $18.23 \mathrm{mg} \mathrm{Cl}^{-} \mathrm{g}^{-1} \mathrm{DW}$ in leaf tissues, respectively; the $\mathrm{Cl}^{-}$. including tomato and tobacco plants accumulated 32.33 and $55.10 \mathrm{mg} \mathrm{Cl}^{-} \mathrm{g}^{-1} \mathrm{DW}$ in leaf tissues, respectively; and the strong $\mathrm{Cl}^{-}$-including leafy vegetables lettuce, spinach, and chard accumulated 76.71, 80.86, and $107.12 \mathrm{mg} \mathrm{Cl}^{-} \mathrm{g}^{-1} \mathrm{DW}$ in leaf tissues, respectively. It is noteworthy that $\mathrm{Cl}^{-}$improved biomass and $\mathrm{NU}_{\mathrm{T}} \mathrm{E}$ in all the species tested (Figure 4), with the exception of olive, which was the species with the lowest $\mathrm{Cl}^{-}$accumulation ability (Table 1 ). Thus, $\mathrm{Cl}^{-}$stimulated plant biomass (Figure 4A), reduced leaf $\mathrm{NO}_{3}{ }^{-}$content (Figure 4B and Supplementary Table S4) and $\mathrm{NU}_{\mathrm{PE}}$ (Figure $4 \mathrm{C}$ ), and stimulated $\mathrm{NU}_{\mathrm{T}} \mathrm{E}$ (Figure $4 \mathrm{D}$ ). These responses showed a clear correlation with the content of $\mathrm{Cl}^{-}$accumulated in the leaves of the different plant species, up to a value of $\sim 50 \mathrm{mg} \mathrm{Cl}^{-} \mathrm{g}^{-1}$ DW in tobacco leaves. Species accumulating higher $\mathrm{Cl}^{-}$contents showed a saturation response (Figure 4).

It is worth mentioning that, as previously described in tobacco plants (Franco-Navarro et al., 2016), $\mathrm{Cl}^{-}$nutrition significantly increased water content of all the tested plant species except for the $\mathrm{Cl}^{-}$excluders olive and Cleopatra mandarin (Supplementary Table S4). Notably, $\mathrm{NO}_{3}{ }^{-}$content significantly decreased by the application of $\mathrm{Cl}^{-}$in all species tested (Figure 4B and Supplementary Table S4). Regarding TNC, we observed that, in comparison to the SP treatment, the $\mathrm{Cl}^{-}$treatment did not induce significant changes in olive, lettuce, and spinach (as in tobacco plants; Figure 1D), whereas a slight decrease was found in other species like tomato, Cleopatra mandarin, and chard (Table 1). Interestingly, $\mathrm{NU}_{\mathrm{P}} \mathrm{E}$ was unaffected in the poor $\mathrm{Cl}^{-}$ 

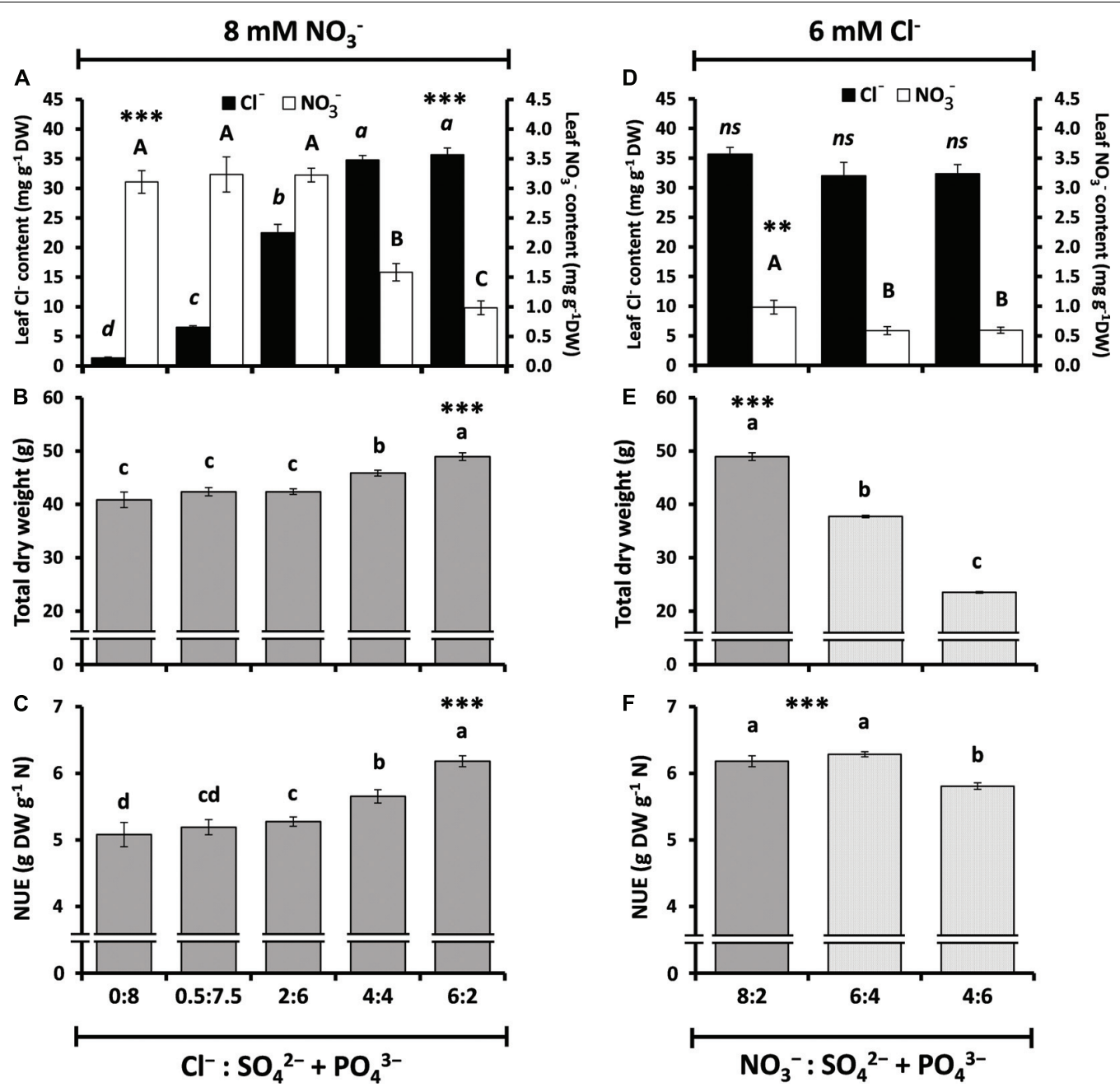

FIGURE 3 | Effect of different ratios of $\mathrm{Cl}^{-}$nutrition on anion content, plant growth, and nitrogen use efficiency (NUE) in tobacco plants. Treatments consisted of the application of: (A-C; $\uparrow \mathrm{Cl}^{-} / \downarrow \mathrm{SO}_{4}{ }^{2-}+\mathrm{PO}_{4}{ }^{3-}$ ) increasing concentrations of $\mathrm{Cl}^{-}$(from 0.075 to $6 \mathrm{mM}$ ) and decreasing concentrations of $\mathrm{SO}_{4}{ }^{2-}+\mathrm{PO}_{4}{ }^{3-}$ (from 8 to $2 \mathrm{mM}$ ) while keeping constant the concentration of $\mathrm{NO}_{3}{ }^{-}(8 \mathrm{mM})$; and (D-F; $\downarrow \mathrm{NO}_{3}{ }^{-} / \uparrow \mathrm{SO}_{4}{ }^{2-}+\mathrm{PO}_{4}{ }^{3-}$ ) decreasing concentrations of $\mathrm{NO}_{3}{ }^{-}$(from 8 to $4 \mathrm{mM}$ ) and increasing concentrations of $\mathrm{SO}_{4}{ }^{2-}+\mathrm{PO}_{4}{ }^{3-}$ (from 2 to $6 \mathrm{mM}$ ) while keeping constant the concentration of $\mathrm{Cl}^{-}(6 \mathrm{mM})$. (A,D) Effect on leaf anion contents ( $\mathrm{NO}_{3}{ }^{-}$ and $\mathrm{Cl}^{-}$). (B,E) Effect on total dry weight (DW). (C,F) Effect on nitrogen-use efficiency (NUE). Mean values $\pm \mathrm{SE}, n=6$. Levels of significance: $P>0.05$ (ns, not significant differences); ${ }^{* * *} P \leq 0.001$; and "homogeneous group" statistics was calculated through ANOVA tests, where mean values with different letters are significantly different according toTukey's test.

including species (olive and Cleopatra mandarin), whereas it was moderately reduced $(\sim 20 \%)$ in the $\mathrm{Cl}^{-}$-including species (Figure 4C). Thus, the increase in leaf $\mathrm{Cl}^{-}$accumulation showed positive correlations with biomass and $\mathrm{NU}_{\mathrm{T}} \mathrm{E}$ among the species (Figures 4A,D). These results indicate that the beneficial effect of $\mathrm{Cl}^{-}$as a macronutrient on plant growth and NUE is a highly relevant phenomenon that could be extended to cultivated plants.

\section{DISCUSSION}

$\mathrm{NO}_{3}{ }^{-}$, an essential source of $\mathrm{N}$, and $\mathrm{Cl}^{-}$, an important osmoregulatory molecule and beneficial macronutrient, are the most abundant inorganic anions in plants, and both must be coordinately incorporated during the active growth of plants
(Cubero-Font et al., 2016; Colmenero-Flores et al., 2019). Both anions play important roles in charge balance and turgor regulation, showing strong dynamic interactions in land plants (Wege et al., 2017; Geilfus, 2018; Colmenero-Flores et al., 2019). Since $\mathrm{NO}_{3}^{-}$and $\mathrm{Cl}^{-}$also present similar physical properties in solution, they share ion transport mechanisms with uncertain selectivities for both anions. $\mathrm{NO}_{3}{ }^{-}$, as a source of the essential macronutrient $\mathrm{N}$, is assimilated during anabolic metabolism, while $\mathrm{Cl}^{-}$, which is not metabolized, becomes accumulated in plant tissues. Interaction between $\mathrm{NO}_{3}{ }^{-}$and $\mathrm{Cl}^{-}$has been traditionally understood as antagonistic. For instance, a high tissue content of $\mathrm{Cl}^{-}$is believed to reduce the content of $\mathrm{NO}_{3}{ }^{-}$and vice versa (Xu et al., 2000; Umar and Iqbal, 2007). The presence of external $\mathrm{NO}_{3}{ }^{-}$has been shown to inhibit root $\mathrm{Cl}^{-}$uptake (Glass and Siddiqi, 1985; 
TABLE 1 | Effect of $\mathrm{Cl}^{-}$nutrition on biomass, anion content and NUE parameters in different species of agronomic interest.

\begin{tabular}{|c|c|c|c|c|c|c|c|c|c|}
\hline \multirow[t]{2}{*}{ Family } & \multirow[t]{2}{*}{ Species } & \multirow[t]{2}{*}{ N.T. } & \multirow{2}{*}{$\begin{array}{c}\text { Total plant } \\
\text { biomass (g DW) }\end{array}$} & \multicolumn{6}{|c|}{ Anion content and NUE parameters } \\
\hline & & & & $\begin{array}{c}\mathrm{Cl}^{-}\left(\mathrm{mg} \mathrm{g}^{-1}\right. \\
\mathrm{DW})\end{array}$ & $\begin{array}{c}\mathrm{NO}_{3}-\left(\mathrm{mg} \mathrm{g}^{-1}\right. \\
\mathrm{DW})\end{array}$ & $\begin{array}{c}\text { TNC }\left(\mathrm{mg} \mathrm{g}^{-1}\right. \\
\text { DW) }\end{array}$ & $\begin{array}{l}\mathrm{NU}_{\mathrm{P}} \mathrm{E}(\mathrm{mg} \mathrm{N} \\
\left.\mathrm{g}^{-1} \text { root } \mathrm{DW}\right)\end{array}$ & $\begin{array}{c}\mathrm{NU}_{T} \mathrm{E}\left(\mathrm{g}^{2} \mathrm{DW}\right. \\
\left.\mathrm{mg}^{-1} \mathrm{~N}\right)\end{array}$ & $\begin{array}{c}\text { NUE (g DW } \\
\left.\mathrm{mg}^{-1} \mathrm{~N}\right)\end{array}$ \\
\hline \multirow[t]{3}{*}{ Solanaceae } & Tomato & $\mathrm{SP}$ & $34.20 \pm 0.66$ & $0.73 \pm 0.02$ & $4.10 \pm 0.35$ & $36.86 \pm 0.54$ & $707.9 \pm 29.1$ & $0.93 \pm 0.02$ & $105.05 \pm 2.04$ \\
\hline & & $\mathrm{CL}$ & $47.81 \pm 0.79$ & $32.33 \pm 1.12$ & $2.20 \pm 0.41$ & $31.85 \pm 0.61$ & $555.3 \pm 31.2$ & $1.51 \pm 0.05$ & $146.86 \pm 2.42$ \\
\hline & & $P$-value & 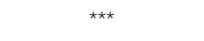 & 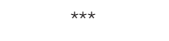 & $\star \star$ & 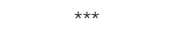 & ** & $\star \star \star *$ & 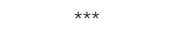 \\
\hline \multirow[t]{3}{*}{ Oleaceae } & Olive & $\mathrm{SP}$ & $0.44 \pm 0.03$ & $1.67 \pm 0.31$ & $2.40 \pm 0.09$ & $27.70 \pm 1.57$ & $258.8 \pm 14.6$ & $0.016 \pm 0.001$ & $1.36 \pm 0.10$ \\
\hline & & $\mathrm{CL}$ & $0.40 \pm 0.08$ & $7.36 \pm 0.79$ & $1.71 \pm 0.20$ & $28.06 \pm 1.28$ & $257.1 \pm 11.7$ & $0.014 \pm 0.003$ & $1.24 \pm 0.24$ \\
\hline & & $P$-value & ns & $\star \star * *$ & * & ns & ns & ns & ns \\
\hline \multirow[t]{3}{*}{ Rutaceae } & Mandarin & $\mathrm{SP}$ & $9.68 \pm 0.13$ & $1.03 \pm 0.09$ & $3.46 \pm 0.52$ & $26.07 \pm 1.04$ & $444.7 \pm 14.3$ & $0.37 \pm 0.02$ & $28.67 \pm 0.33$ \\
\hline & & $\mathrm{CL}$ & $11.02 \pm 0.28$ & $18.23 \pm 0.36$ & $2.11 \pm 0.11$ & $23.52 \pm 0.48$ & $452.6 \pm 2.88$ & $0.47 \pm 0.01$ & $32.29 \pm 0.59$ \\
\hline & & $P$-value & $\star \star$ & $\star \star \star$ & * & * & ns & $\star \star$ & * \\
\hline \multirow[t]{3}{*}{ Asteraceae } & Lettuce & $\mathrm{SP}$ & $18.42 \pm 0.91$ & $16.47 \pm 2.02$ & $9.04 \pm 0.20$ & $23.94 \pm 1.02$ & $221.4 \pm 9.47$ & $0.78 \pm 0.07$ & $56.58 \pm 2.80$ \\
\hline & & $\mathrm{CL}$ & $27.95 \pm 3.19$ & $76.71 \pm 2.13$ & $7.56 \pm 0.50$ & $23.39 \pm 1.48$ & $175.9 \pm 11.1$ & $1.20 \pm 0.14$ & $85.86 \pm 9.79$ \\
\hline & & $P$-value & * & $\star * *$ & * & ns & * & * & * \\
\hline \multirow[t]{6}{*}{ Amaranthaceae } & Spinach & $\mathrm{SP}$ & $7.23 \pm 0.36$ & $12.29 \pm 1.07$ & $4.79 \pm 0.26$ & $26.79 \pm 1.39$ & $247.7 \pm 12.8$ & $0.27 \pm 0.02$ & $45.25 \pm 1.21$ \\
\hline & & $\mathrm{CL}$ & $9.07 \pm 0.37$ & $80.86 \pm 4.14$ & $4.45 \pm 0.05$ & $25.22 \pm 0.68$ & $189.6 \pm 5.14$ & $0.36 \pm 0.02$ & $55.13 \pm 2.97$ \\
\hline & & $P$-value & * & $\star * *$ & ns & ns & * & * & * \\
\hline & Chard & $\mathrm{SP}$ & $14.73 \pm 0.39$ & $10.82 \pm 0.54$ & $7.41 \pm 0.34$ & $21.48 \pm 0.50$ & $198.6 \pm 4.60$ & $0.69 \pm 0.01$ & $56.58 \pm 2.80$ \\
\hline & & $\mathrm{CL}$ & $17.95 \pm 0.97$ & $107.1 \pm 3.35$ & $5.57 \pm 0.26$ & $18.99 \pm 0.59$ & $142.8 \pm 4.40$ & $0.95 \pm 0.07$ & $85.86 \pm 9.79$ \\
\hline & & $P$-value & * & *** & $\star *$ & * & $\star \star \star ~$ & * & * \\
\hline
\end{tabular}

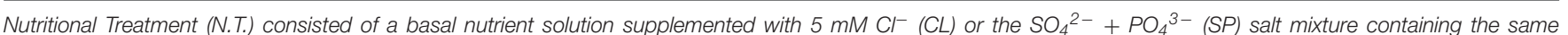

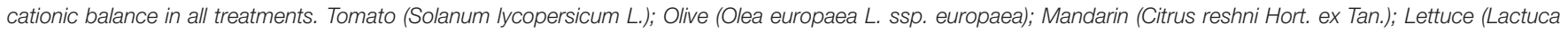

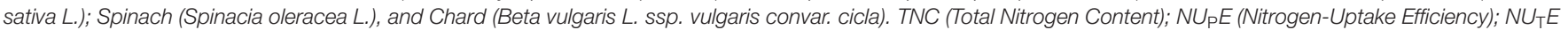

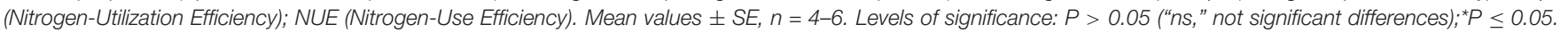
${ }^{* *} P \leq 0.01$. ${ }^{* *} P \leq 0.001$. "Homogeneous group" statistics was calculated through ANOVA test. DW, dry weight.

Iglesias et al., 2004), and on the contrary, high $\mathrm{Cl}^{-}$content reduces $\mathrm{NO}_{3}{ }^{-}$accumulation in plants, suggesting that common transport mechanisms could facilitate the influx of both anions (Xu et al., 2000; Teakle and Tyerman, 2010). This antagonism between $\mathrm{NO}_{3}{ }^{-}$and $\mathrm{Cl}^{-}$has been widely reported for many crops, pointing to a clear detrimental effect of $\mathrm{Cl}^{-}$on $\mathrm{NO}_{3}{ }^{-}$ nutrition (transport, accumulation, and/or assimilation; Buwalda and Smith, 1991; Cerezo et al., 1997; Xu et al., 2000). As a result, $\mathrm{Cl}^{-}$is considered harmful to crop productivity, to the extent that its presence in some types of plant fertilizers is considered as a negative indicator of their quality (EU Regulation 2019/1009). However, $\mathrm{Cl}^{-}$has been recently defined as a beneficial macronutrient that improves plant development, water relations, $\mathrm{CO}_{2}$ assimilation, and wateruse efficiency when supplemented at concentrations higher than those necessary to satisfy micronutrient requirements but insufficient to cause toxicity (e.g., in the beneficial range of 1-5 $\mathrm{mM} \mathrm{Cl}^{-}$; Colmenero-Flores et al., 2019; Franco-Navarro et al., 2019). The fact that $\mathrm{Cl}^{-}$specifically promotes plant biomass due to these beneficial effects (Franco-Navarro et al., 2016) is difficult to reconcile with a detrimental effect on $\mathrm{NO}_{3}{ }^{-}$nutrition.

Consistent with our previous findings (Franco-Navarro et al., 2016, 2019), tobacco plants accumulated $\mathrm{Cl}^{-}$at levels that are typical of a macronutrient, stimulating plant growth when applied at concentrations above $1 \mathrm{mM} \mathrm{Cl}^{-}$(Figures 1A, 2A). Furthermore, although leaf $\mathrm{Cl}^{-}$content was $\sim 120$ times lower in
SP and $\mathrm{N}$ plants in comparison to $\mathrm{CL}$, it remained over the critical threshold of $\mathrm{Cl}^{-}$deficiency reported for non-halophytic plants (<0.2 $\mathrm{mg} \mathrm{g}^{-1}$ shoot DW; Flowers, 1988; Xu et al., 2000; White and Broadley, 2001; Franco-Navarro et al., 2016), which ruled out the occurrence of $\mathrm{Cl}^{-}$deficiency in SP and $\mathrm{N}$ treatments. Moreover, the higher growth of $\mathrm{N}$ plants (Figure 1A) confirmed this point and strengthens the well-known fact that $\mathrm{NO}_{3}{ }^{-}$has a strong impact on plant growth and development (Glass, 2003; Hawkesford et al., 2012; Wang et al., 2012; Krapp et al., 2014; Guan, 2017).

NUE is an important crop trait described as a useful tool to improve agricultural systems (Fageria et al., 2008). This work clearly states that, contrary to what was previously believed, $\mathrm{Cl}^{-}$ improves NUE in plants, at least when $\mathrm{NO}_{3}{ }^{-}$is used as the sole $\mathrm{N}$ source. The decline in leaf biomass has been directly correlated to $\mathrm{N}$ deficiency particularly in tobacco plants (Balachandran et al., 1997), since this crop requires high quantities of $\mathrm{NO}_{3}{ }^{-}$ for maximum vegetative yield (Ruiz et al., 2006). Considering that $\mathrm{N}$ is not only an essential nutrient for optimal crop yield but also an environmental concern, adequate management of $\mathrm{N}$ fertilization regimes to enhance NUE remains critical for crop breeding. Our results confirm that $\mathrm{Cl}^{-}$significantly increases NUE, not only in tobacco plants (Figures 1, 2) but also in different crop species (Figure 4), when accumulated at macronutrient levels. NUE improvement in tobacco plants was a consequence of more efficient use of the $\mathrm{NO}_{3}{ }^{-}$taken up by the plant $\left(\mathrm{NU}_{\mathrm{T}} \mathrm{E}\right.$; Figures $\left.2 \mathrm{D}, 3 \mathrm{C}\right)$, meaning that $\mathrm{Cl}^{-}$ 

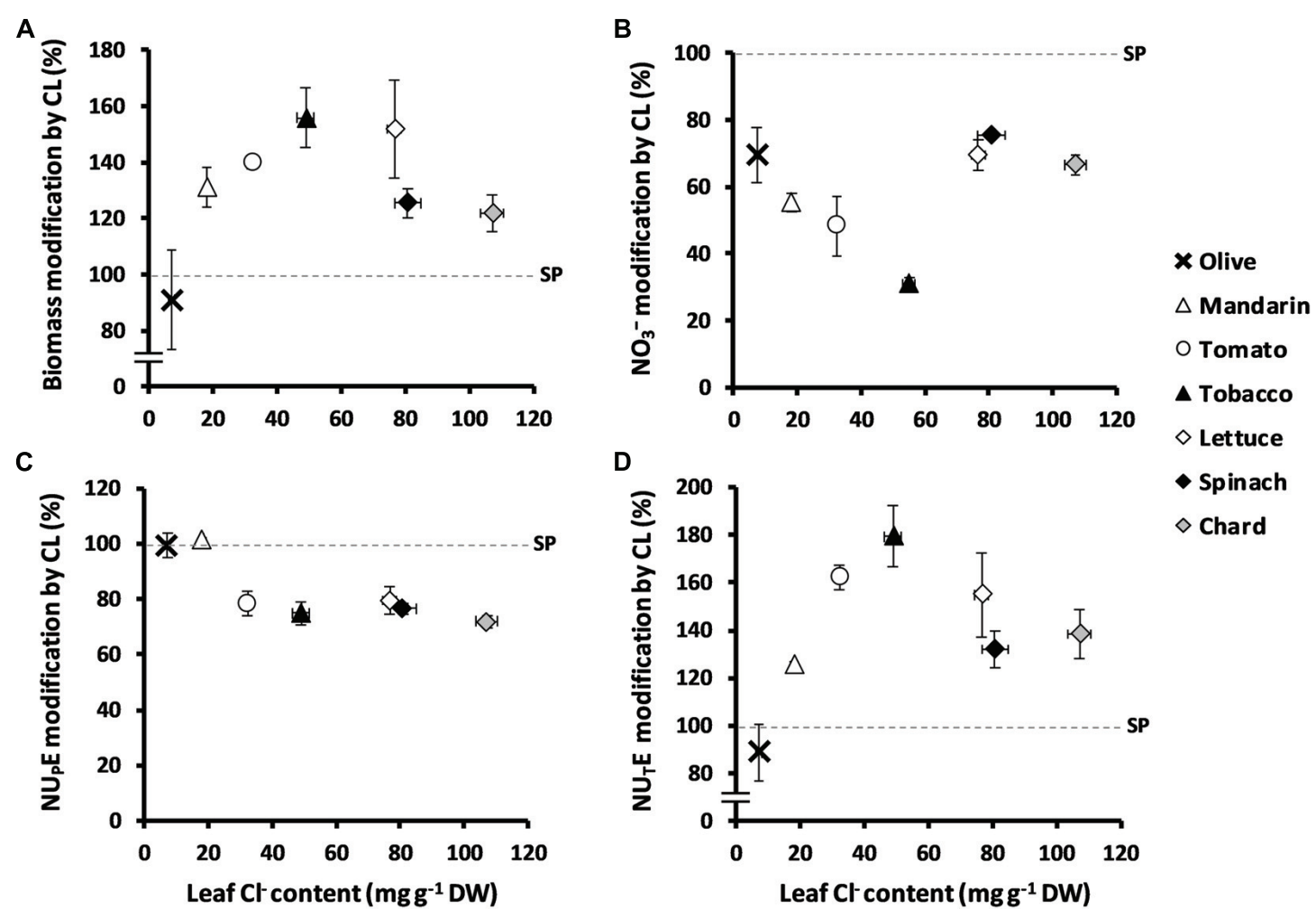

FIGURE 4 | Effect of $\mathrm{Cl}^{-}$nutrition on plant growth, $\mathrm{NO}_{3}{ }^{-}$content, $\mathrm{N}$ uptake efficiency ( $\mathrm{NU}_{\mathrm{P}} \mathrm{E}$ ), and $\mathrm{N}$ utilization efficiency ( $\mathrm{NU} \mathrm{T}_{\mathrm{T}} \mathrm{E}$ ) in several species of agronomic interest. Plants were treated with two nutritional treatments: $5 \mathrm{mM} \mathrm{Cl}^{-}$salts $(\mathrm{CL})$ and a mixture of $\mathrm{SO}_{4}{ }^{2-}+\mathrm{PO}_{4}{ }^{3-}$ salts (SP) containing the same cationic balance as in the $\mathrm{CL}$ treatment. Ratios of total biomass (A), $\mathrm{NO}_{3}{ }^{-}$content expressed as $\mathrm{mg} \mathrm{kg}^{-1}$ of fresh weight (B), $\mathrm{NU} \mathrm{P}_{\mathrm{P}}$ (C), and $\mathrm{NU} \mathrm{T}_{\mathrm{T}} \mathrm{E}$ (D) are presented considering the \% of CL in relation to SP treatment and in contrast to leaf anion content in several species. Olive (Olea europaea L. ssp. europaea; bold cross), mandarin (Citrus reshni Hort. ex Tan; open triangles), tomato (Solanum lycopersicum L.; open circles), tobacco (Nicotiana tabacum L.; filled triangles), lettuce (Lactuca sativa L.; open diamonds); spinach (Spinacia oleracea L.; filled diamonds), and chard (Beta vulgaris L. ssp. vulgaris; gray-colored diamonds); mean values \pm SE, $n=6$.

improves $\mathrm{NO}_{3}{ }^{-}$assimilation, as observed in other crop species (Figure 4D). A significant positive correlation $\left(r^{2}=0.995\right)$ between leaf $\mathrm{Cl}^{-}$content and $\mathrm{NU}_{\mathrm{T}} \mathrm{E}$ was established in tobacco plants (Figure 2F). Interestingly, this positive correlation was also observed in different plant species with contrasting abilities to accumulate $\mathrm{Cl}^{-}$(Figure $4 \mathrm{D}$ ). Thus, $\mathrm{NU}_{\mathrm{T}} \mathrm{E}$ gain by $\mathrm{Cl}^{-}$ application was minimal in $\mathrm{Cl}^{-}$excluding species $(0-22 \%$ $\mathrm{NU}_{\mathrm{T}} \mathrm{E}$ increment in olive and the citrus rootstock Cleopatra mandarin plants, respectively) and maximal in $\mathrm{Cl}^{-}$including ones $\left(60-80 \% \mathrm{NU}_{\mathrm{T}} \mathrm{E}\right.$ increment in tomato and tobacco plants, respectively), indicating a positive ecophysiological correlation between leaf $\mathrm{Cl}^{-}$accumulation and $\mathrm{NU}_{\mathrm{T}} \mathrm{E}$. However, this correlation was lost in strong $\mathrm{Cl}^{-}$including vegetables (30$55 \% \mathrm{NU}_{\mathrm{T}} \mathrm{E}$ increment in the large-leaved spinach, chard, and lettuce plants), suggesting the occurrence of a saturable response, possibly as a consequence of excessive $\mathrm{Cl}^{-}$accumulation. This positive correlation between $\mathrm{Cl}^{-}$content and $\mathrm{NU}_{\mathrm{T}} \mathrm{E}$ can be a selection criterion to identify new cultivars or genotypes obtained from breeding programs, with potentially improved NUE capacity. Thus, genotypes that, in the presence of $5 \mathrm{mM}$ $\mathrm{Cl}^{-}$, show leaf $\mathrm{Cl}^{-}$contents between 20 and $50 \mathrm{mg} \mathrm{g}^{-1} \mathrm{DW}$ (Table 1), within the positive linear response range shown in Figure 4D, could be good candidates not only for improved
NUE but also for higher efficiency in the use of water and $\mathrm{CO}_{2}$ (Colmenero-Flores et al., 2019).

These results were obtained comparing SP and CL treatments, both containing the same $\mathrm{NO}_{3}{ }^{-}$concentration $\left(5 \mathrm{mM} \mathrm{NO}_{3}{ }^{-}\right.$). However, $\mathrm{NU}_{\mathrm{T}} \mathrm{E}$ stimulation by $\mathrm{Cl}^{-}$was much higher when the $\mathrm{CL}$ treatment was compared with the $\mathrm{N}$ treatment $(10.25 \mathrm{mM}$ $\mathrm{NO}_{3}{ }^{-}$). The increase in $\mathrm{NU}_{\mathrm{T}} \mathrm{E}$ in $\mathrm{CL}$ vs. $\mathrm{N}$ tobacco plants was $\sim 250 \%$ (Figure 1F), suggesting that $\mathrm{NO}_{3}{ }^{-}$fertilization in the field can be efficiently regulated if optimal supplies of $\mathrm{NO}_{3}{ }^{-} / \mathrm{Cl}^{-}$ ratios are used. Thus, increasing the $\mathrm{Cl}^{-} / \mathrm{NO}_{3}{ }^{-}$ratio showed two positive effects on plants: reduction in leaf $\mathrm{NO}_{3}{ }^{-}$content (Figure 3A) while at the same time increasing plant biomass (Figure 3B). Different studies have proposed a negative effect of $\mathrm{Cl}^{-}$on $\mathrm{NO}_{3}{ }^{-}$uptake and accumulation (Siddiqi et al., 1990; Cerezo et al., 1997; Li et al., 2017), which is supposed to reduce NUE. Nevertheless, our results ruled out the possibility that $\mathrm{Cl}^{-}$impairs $\mathrm{N}$ use because the $\mathrm{CL}$ treatment increased plant biomass (Figure 3B), while the effective reduction in $\mathrm{NO}_{3}{ }^{-}$in the nutrient solution produced a strong reduction in plant biomass (Figure 3E). This clearly indicates that the loss of leaf $\mathrm{NO}_{3}{ }^{-}$content through $\mathrm{Cl}^{-}$application is not a consequence of lower root $\mathrm{NO}_{3}{ }^{-}$uptake (e.g., lower $\mathrm{NO}_{3}{ }^{-}$ availability as a consequence of $\mathrm{Cl}^{-}$antagonism; Figure 2C) 
but of a greater $\mathrm{NO}_{3}{ }^{-}$assimilation capacity. The $\mathrm{NO}_{3}{ }^{-}$vs. $\mathrm{Cl}^{-}$ antagonism must be understood in terms of the selectivity of anion transporters. Given the great relevance of $\mathrm{N}$ for plant nutrition, plants prioritize $\mathrm{NO}_{3}{ }^{-}$uptake over $\mathrm{Cl}^{-}$uptake when $\mathrm{NO}_{3}{ }^{-}$is available in the soil. This means that active transport mechanisms are normally more selective for $\mathrm{NO}_{3}{ }^{-}$than for $\mathrm{Cl}^{-}$ (Glass and Siddiqi, 1985; Wege et al., 2017; Wen et al., 2017). Consequently, increasing the $\mathrm{NO}_{3}{ }^{-}$concentration in the nutrient solution reduces $\mathrm{Cl}^{-}$content in plants (Glass and Siddiqi, 1985; Iglesias et al., 2004). However, the opposite situation is not necessarily true. Although widely reported (Xu et al., 2000; and references therein), $\mathrm{Cl}^{-}$application in the low millimolar range should not impair $\mathrm{NO}_{3}{ }^{-}$uptake given the high selectivity for $\mathrm{NO}_{3}{ }^{-}$over $\mathrm{Cl}^{-}$. Thus, total $\mathrm{N}$ content of plants does not decrease in response to $\mathrm{Cl}^{-}$application (Figure 1D; Ourry et al., 1992; Liu and Shelp, 1996; Inal et al., 1998). However, in Figure $4 \mathrm{C}$, a moderate reduction in $\mathrm{NU}_{\mathrm{P}} \mathrm{E}$ can be observed in different plant species in response to $\mathrm{Cl}^{-}$application. Rather than an effective reduction in $\mathrm{NO}_{3}{ }^{-}$uptake transport through transmembrane transporters at the soil-root interface, $\mathrm{NU}_{\mathrm{P}} \mathrm{E}$ reduction can be a consequence of the calculation procedure. The $\mathrm{NU}_{\mathrm{P}} \mathrm{E}$ formula computes the $\mathrm{NO}_{3}{ }^{-}$content in plant tissues, which is lower in plants treated with $\mathrm{Cl}^{-}$because $\mathrm{NO}_{3}{ }^{-}$is more efficiently assimilated, as is also proposed by Liu and Shelp (1996). It is very likely, however, that under salinity stress conditions, $\mathrm{Cl}^{-}$antagonizes $\mathrm{NO}_{3}{ }^{-}$influx in plant cells, significantly reducing root $\mathrm{NO}_{3}{ }^{-}$uptake (Cerezo et al., 1997; Li et al., 2017).

Therefore, our results strongly support the previously suggested role of $\mathrm{Cl}^{-}$as preferred plant osmoregulatory molecule in plants (Flowers, 1988; Franco-Navarro et al., 2016; ColmeneroFlores et al., 2019). Thus, we propose that, on the one hand, $\mathrm{Cl}^{-}$is preferably compartmentalized in the vacuole. On the other hand, $\mathrm{NO}_{3}{ }^{-}$, an essential $\mathrm{N}$ source for land plants, is preferentially assimilated, which is not possible when this molecule is sequestered in the vacuole to carrry out an osmotic function. Only when $\mathrm{Cl}^{-}$is not sufficiently available in the soil, or as a result of excessive $\mathrm{NO}_{3}{ }^{-}$availability, $\mathrm{NO}_{3}{ }^{-}$ could be preferentially compartmentalized (Siddiqi et al., 1991; Radcliffe et al., 2005). Therefore, macronutrient accumulation of $\mathrm{Cl}^{-}$reduces $\mathrm{NO}_{3}^{-}$compartmentalization in the vacuole, facilitating its assimilation, which increases NUE and plant biomass. Under the same premise, $\mathrm{Cl}^{-}$should also play an adaptive role to improve plant growth under conditions of low $\mathrm{N}$ availability, which is also explained in terms of differential transport selectivity. When little $\mathrm{NO}_{3}{ }^{-}$is available, root $\mathrm{Cl}^{-}$ uptake through active anion transporters is less inhibited (Wen et al., 2017), increasing cell $\mathrm{Cl}^{-}$content and replacing $\mathrm{NO}_{3}{ }^{-}$ in the vacuole, which facilitates $\mathrm{NO}_{3}{ }^{-}$assimilation and NUE. A clear demonstration that the relationship between $\mathrm{Cl}^{-}$and $\mathrm{NO}_{3}{ }^{-}$homeostasis in higher plants is not limited to an antagonistic interaction has been recently shown by CuberoFont et al. (2016). This work describes a molecular mechanism that determines the rate of $\mathrm{NO}_{3}{ }^{-} / \mathrm{Cl}^{-}$accumulation in aerial organs of Arabidopsis thaliana based on the $\mathrm{Cl}^{-}$conductance of the AtSLAH3 channel, which is in turn regulated by environmental cues.
Agronomic and scientific communities have traditionally believed that little amounts of $\mathrm{Cl}^{-}$are required to achieve suitable crop yields (Geilfus, 2018). Nevertheless, some studies have shown that the application of $\mathrm{Cl}^{-}$-enriched fertilizers to the soil increases the vegetative yield in different crops (Christensen et al., 1981; Timm et al., 1986; Inal et al., 1998; $\mathrm{Xu}$ et al., 2000). However, it was not clear to what extent plant yield improvement was due to the accompanying cations or whether other anions could replace $\mathrm{Cl}^{-}$in the reported growth-promoting effects. In accordance with the recently revealed functions of $\mathrm{Cl}^{-}$as a beneficial macronutrient (FrancoNavarro et al., 2016; Colmenero-Flores et al., 2019), it has been proven that a number of physiological perturbations impairing the growth and yield of durum wheat under field conditions are specifically due to soil $\mathrm{Cl}^{-}$deficiency (Schwenke et al., 2015). Hence, we investigated how crops could benefit from certain levels of $\mathrm{Cl}^{-}$fertilization. In the herbaceous species studied (i.e., tomato, lettuce, spinach, and chard), the $5 \mathrm{mM} \mathrm{Cl}^{-}$treatment determined plant biomass gains in accordance with the leaf $\mathrm{Cl}^{-}$content within the beneficial macronutrient range (40-110 $\mathrm{mg} \mathrm{g}^{-1} \mathrm{DW}$; Colmenero-Flores et al., 2019; Figure 3B). These $\mathrm{Cl}^{-}$content values are up to an order of magnitude above what was classically considered toxic concentrations in plants ( $\mathrm{Xu}$ et al., 2000), largely dismantling this view of $\mathrm{Cl}^{-}$as detrimental to agriculture (Colmenero-Flores et al., 2019).

Given the high $\mathrm{NO}_{3}{ }^{-}$content in fertilizers and its often abusive use in agriculture, $\mathrm{NO}_{3}{ }^{-}$can be excessively accumulated in the leaves of most horticultural crops, resulting in food safety problems (e.g., methemoglobinemia and cancer) because of its transformation into nitrites and nitrosamines (Colla et al., 2018). This is particularly harmful in leafy vegetables, for which the European Commission has developed severe regulations (1881/2006 and 1258/2011) to reduce the excessive dietary intake of $\mathrm{NO}_{3}{ }^{-}$, especially that of vulnerable people such as infants, the elderly, and vegetarians. As previously stressed, increasing the $\mathrm{Cl}^{-} / \mathrm{NO}_{3}{ }^{-}$ratios reduced the leaf $\mathrm{NO}_{3}{ }^{-}$ content (Figure 3A) without impairing, or even increasing, plant biomass (Figure 3B). In our study, the $\mathrm{NO}_{3}{ }^{-}$content in leafy species (lettuce, spinach, and chard) treated with SP ranged between 577 and $1,035 \mathrm{mg} \mathrm{NO}{ }^{-} \mathrm{kg}^{-1} \mathrm{FW}$ (Supplementary Table S4), proving to be much lower than the maximum permitted levels, which are set at 3,500 and 2,500 $\mathrm{mg} \mathrm{NO}_{3}{ }^{-} \mathrm{kg}^{-1} \mathrm{FW}$ in spinach and iceberg lettuce, respectively. It should be noted, however, that the SP treatment contains $5 \mathrm{mM} \mathrm{NO}_{3}^{-}$, probably well below the levels applied in the field by farmers. Chloride reduced about $25-70 \%$ the $\mathrm{NO}_{3}{ }^{-}$content in the plant species assayed (compared to SP plants; Figure 4B). These results are in accordance with those reported by Urrestarazu et al. (1998) in lettuce, Inal et al. (1998) in carrot, and Borgognone et al. (2016) in cardoon. Therefore, $\mathrm{Cl}^{-}$nutrition is expected to considerably improve the nutritional quality of vegetables and brings to light the important benefits of using $\mathrm{Cl}^{-}$-enriched fertilizers in human health. Interestingly, $\mathrm{Cl}^{-}$-treated tobacco plants showed the strongest decrease in $\mathrm{NO}_{3}{ }^{-}$content $(\sim 70 \%$ compared to SP plants; Figure 4B). Considering that $\mathrm{NO}_{3}{ }^{-}$is the main inducer 
of nitrogen oxides and nitrosamines in flue-cured tobacco during smoking (Hoffmann and Hecht, 1985), $\mathrm{Cl}^{-}$nutrition could also help to reduce the nitrosamine levels in cigarettes, improving the quality of this crop.

\section{CONCLUSION}

We provide for the first time a direct demonstration which shows that $\mathrm{Cl}^{-}$, contrary to impairing $\mathrm{NO}_{3}{ }^{-}$nutrition, facilitates $\mathrm{NO}_{3}{ }^{-}$ utilization and improves NUE in plants. This is largely due to $\mathrm{Cl}^{-}$improvement of $\mathrm{NU}_{\mathrm{T}} \mathrm{E}$, having a little or moderate effect on $\mathrm{NU}_{\mathrm{P}} \mathrm{E}$ when $\mathrm{NO}_{3}{ }^{-}$is used as the sole $\mathrm{N}$ source in the nutrient solution. Clear positive correlations between leaf $\mathrm{Cl}^{-}$content vs. $\mathrm{NU}_{\mathrm{T}} \mathrm{E}$ or vs. plant growth have been established at both intra- and interspecies levels: in tobacco plants treated with growing $\mathrm{Cl}^{-}$ concentrations and comparing different species with contrasting abilities to accumulate $\mathrm{Cl}^{-}$. Our results strongly suggest that macronutrient $\mathrm{Cl}^{-}$nutrition reduces $\mathrm{NO}_{3}{ }^{-}$sequestration in plant leaf tissues (e.g., vacuolar compartmentalization), making this valuable $\mathrm{N}$ source available for assimilation and biosynthesis of organic N. Our results give light to a brand-new interpretation of $\mathrm{Cl}^{-}$properties as a beneficial macronutrient for higher plants that promote more efficient use of water, carbon, and nitrogen, becoming a potential resource to improve agricultural production and quality, reducing $\mathrm{NO}_{3}{ }^{-}$inputs in the field and unhealthy leaf $\mathrm{NO}_{3}-$ content in vegetables.

\section{DATA AVAILABILITY STATEMENT}

The datasets generated for this study are available on request to the corresponding author.

\section{REFERENCES}

Anjana, S. U., and Iqbal, M. (2007). Nitrate accumulation in plants, factors affecting the process, and human health implications: a review. Agron. Sustain. Dev. 27, 45-57.

Balachandran, S., Hull, R. J., Martins, R. A., Vaadia, Y., and Lucas, W. F. (1997). Influence of environmental stress on biomass partitioning in transgenic tobacco plants expressing the movement protein of tobacco mosaic virus. Plant Physiol. 114, 475-481. doi: 10.1104/pp.114.2.475

Baligar, V. C., Fageria, N. K., and He, Z. L. (2001). Nutrient use efficiency in plants. Commun. Soil Sci. Plant Anal. 32, 921-950.

Borgognone, D., Rouphael, Y., Cardarelli, M., Licini, L., and Colla, G. (2016). Changes in biomass, mineral composition, and quality of cardoon in response to $\mathrm{NO}_{3}{ }^{-}: \mathrm{Cl}^{-}$ratio and nitrate deprivation from the nutrient solution. Front. Plant Sci. 7:978. doi: 10.3389/fpls.2016.00978

Bradstreet, R. B. (1954). Kjeldahl method for organic nitrogen. Anal. Chem. 26, 185-187.

Broadley, M., Brown, P., Cakmak, I., Rengel, Z., and Zhao, F. (2012). "Chapter 7 - function of nutrients: micronutrients," in Marschner's Mineral Nutrition of Higher Plants (Third Edition), ed. P. Marschner (San Diego: Academic Press), 191-248.

Brumós, J., Talón, M., Bouhlal, R. Y. M., and Colmenero-Flores, J. M. (2010). Clhomeostasis in includer and excluder citrus rootstocks: transport mechanisms and identification of candidate genes. Plant Cell Environ. 33, 2012-2027.

Buwalda, J. G., and Smith, G. S. (1991). Influence of anions on the potassium status and productivity of kiwifruit (Actinidia deliciosa) vines. Plant Soil 133, 209-218.

\section{AUTHOR CONTRIBUTIONS}

JF-N performed the experiments, analyzed the data, and participated in the writing of the manuscript. PP-T and PD-R participated in the experiments. RÁ participated in the conception of research plans. $\mathrm{MR}$ and JC-F conceived research plans, supervised the experiments, and wrote the manuscript.

\section{FUNDING}

This work was supported by the Spanish Ministry of Science Innovation and Universities-FEDER grants AGL2015-71386$\mathrm{R}$ and RTI2018-094460-B-I00, and by the Spanish National Research Council grants CSIC-201840E132, CSIC-201940E039, and CSIC-201940E077.

\section{ACKNOWLEDGMENTS}

We acknowledge support of the publication fee by the CSIC Open Access Publication Support Initiative through its Unit of Information Resources for Research (URICI). Help, expertise, and technical assistance of A. Vázquez-Rodríguez, F. J. Durán, and E. Gutiérrez-González are gratefully acknowledged.

\section{SUPPLEMENTARY MATERIAL}

The Supplementary Material for this article can be found online at: https://www.frontiersin.org/articles/10.3389/fpls.2020.00442/ full\#supplementary-material

Cerezo, M., Garcia-Agustin, P., Serna, M. D., and Primo-Millo, E. (1997). Kinetics of nitrate uptake by citrus seedlings and inhibitory effects of salinity. Plant Sci. 126, 105-112.

Christensen, N. W., Taylor, R. G., Jackson, T. L., and Mitchell, B. L. (1981). Chloride effects on water potentials and yield of winter wheat infected with take-all root rot. Agron. J. 73, 1053-1058.

Colla, G., Kim, H.-J., Kyriacou, M. C., and Rouphael, Y. (2018). Nitrate in fruits and vegetables. Sci. Hortic. 237, 221-238.

Colmenero-Flores, J. M., Franco-Navarro, J. D., Cubero-Font, P., PeinadoTorrubia, P., and Rosales, M. A. (2019). Chloride as a beneficial macronutrient in higher plants: new roles and regulation. Int. J. Mol. 20:4686. doi: 10.3390/ ijms20194686

Comly, H. H. (1945). Cyanosis in infants caused by nitrates in well water. JAMA-J. Am. Med. Assoc. 129, 112-116.

Cubero-Font, P., Maierhofer, T., Jaslan, J., Rosales Miguel, A., Espartero, J., Díaz-Rueda, P., et al. (2016). Silent S-type anion channel subunit SLAH1 gates SLAH3 open for chloride root-to-shoot translocation. Curr. Biol. 26, 2213-2220. doi: 10.1016/j.cub.2016. 06.045

Elliott, G. C., and Læuchli, A. (1985). Phosphorus efficiency and phosphate-iron interaction in maize 1. Agron. J. 77, 399-403.

Fageria, N. K., Baligar, V. C., and Li, Y. C. (2008). The role of nutrient efficient plants in improving crop yields in the twenty-first century. J. Plant Nutr. 31, 1121-1157.

Flowers, T. J. (1988). "Chloride as a nutrient and as an osmoticum," in Advances. in Plant. Nutrition, Vol. 3, eds P. B. Tinker and A. Laüchli (New York, NY: Praeger), 55-78. 
Franco-Navarro, J. D., Brumós, J., Rosales, M. A., Cubero-Font, P., Talón, M., and Colmenero-Flores, J. M. (2016). Chloride regulates leaf cell size and water relations in tobacco plants. J. Exp. Bot. 67, 873-891. doi: 10.1093/jxb/erv502

Franco-Navarro, J. D., Rosales, M. A., Cubero-Font, P., Calvo, P., Álvarez, R., DíazEspejo, A., et al. (2019). Chloride as macronutrient increases water use efficiency by anatomically-driven reduced stomatal conductance and increased mesophyll diffusion to CO2. Plant J. 99, 815-831. doi: 10.1111/tpj.14423

Frink, C. R., Waggoner, P. E., and Ausubel, J. H. (1999). Nitrogen fertilizer: retrospect and prospect. Proc. Natl. Acad. Sci. U.S.A. 96, 1175-1180.

Geilfus, C. M. (2018). Chloride: from nutrient to toxicant. Plant Cell Physiol. 59, 877-886. doi: 10.1093/pcp/pcy071

Glass, A. D. (2003). Nitrogen use efficiency of crop plants: physiological constraints upon nitrogen absorption. Crit. Rev. Plant Sci. 22, 453-470.

Glass, A. D. M., and Siddiqi, M. Y. (1985). Nitrate inhibition of chloride influx in barley: implications for a proposed chloride homeostat. J. Exp. Bot. 36, 556-566.

Godfray, H. C. J., Beddington, J. R., Crute, I. R., Haddad, L., Lawrence, D., Muir, J. F., et al. (2010). Food security: the challenge of feeding 9 billion people. Science 327, 812-818. doi: $10.1126 /$ science. 1185383

Guan, P. (2017). Dancing with hormones: a current perspective of nitrate signaling and regulation in Arabidopsis. Front. Plant Sci. 8:1697. doi: 10.3389/fpls.2017. 01697

Han, Y. L., Song, H. X., Liao, Q., Yu, Y., Jian, S. F., Lepo, J. E., et al. (2016). Nitrogen use efficiency is mediated by vacuolar nitrate sequestration capacity in roots of Brassica napus. Plant Physiol. 170, 1684-1698. doi: 10.1104/pp.15.01377

Hawkesford, M., Horst, W., Kichey, T., Lambers, H., Schjoerring, J., Møller, I. S., et al. (2012). "Functions of macronutrients," in Marschner's Mineral Nutrition of Higher Plants, (Cambridge, MA: Academic Press), 135-189.

Hoffmann, D., and Hecht, S. S. (1985). Nicotine-derived N-Nitrosamines and tobacco-related cancer: current status and future directions. Cancer Res. 45, 935-944.

Iglesias, D. J., Levy, Y., Gómez-Cadenas, A., Tadeo, F. R., Primo-Millo, E., and Talon, M. (2004). Nitrate improves growth in salt-stressed citrus seedlings through effects on photosynthetic activity and chloride accumulation. Tree Physiol. 24, 1027-1034.

Inal, A., Gunes, A., Alpaslan, M., and Demir, K. (1998). Nitrate versus chloride nutrition effects in a soil-plant system on the growth, nitrate accumulation, and nitrogen, potassium, sodium, calcium, and chloride content of carrot. J. Plant Nutr. 21, 2001-2011.

Johnson, C. M., Stout, P. R., Broyer, T. C., and Carlton, A. B. (1957). Comparative chlorine requirements of different plant species. Plant Soil 8, 337-353.

Kant, S., Bi, Y. M., and Rothstein, S. J. (2011). Understanding plant response to nitrogen limitation for the improvement of crop nitrogen use efficiency. J. Exp. Bot. 62, 1499-1509. doi: 10.1093/jxb/erq297

Krapp, A., David, L. C., Chardin, C., Girin, T., Marmagne, A., Leprince, A. S., et al. (2014). Nitrate transport and signalling in Arabidopsis. J. Exp. Bot. 65, 789-798. doi: $10.1093 / \mathrm{jxb} / \mathrm{eru} 001$

Krom, M. D. (1980). Spectrophotometric determination of ammonia: study of a modified Berthelot reaction using salicylate and dichloroisocianurate. Analyst $105,305-316$.

Li, B., Tester, M., and Gilliham, M. (2017). Chloride on the move. Trends Plant Sci. 22, 236-248. doi: 10.1016/j.tplants.2016.12.004

Liu, L., and Shelp, B. J. (1996). Impact of chloride on nitrate absorption and accumulation by broccoli (Brassica oleracea var. italica). Can. J. Plant Sci. 76, $367-377$.

MAFF (1998). 1997/8 UK monitoring programme of nitrate in lettuce and spinach, food surveillance information sheet $n 8$ 154. London: MAFF.

Maron, L. G. (2019). From foe to friend: the role of chloride as a beneficial macronutrient. Plant J. 99, 813-814. doi: 10.1111/tpj.14498

Mensinga, T. T., Speijers, J. G. A., and Meulenbelt, J. (2003). Health implications of exposure to environmental nitrogenous compounds. Toxicol. Rev. 14:576584.

Moll, R. H., Kamprath, E. J., and Jackson, W. A. (1982). Analysis and interpretation of factors which contribute to efficiency of nitrogen utilization 1. Agron. J. 74, $562-564$.

Nieves-Cordones, M., García-Sánchez, F., Pérez-Pérez, J. G., Colmenero-Flores, J. M., Rubio, F., and Rosales, M. A. (2019). Coping with water shortage: an update on the role of $\mathrm{K}+, \mathrm{Cl}^{-}$, and water transport mechanisms on drought resistance. Front. Plant Sci. 10:1619. doi: 10.3389/fpls.2019.01619
Nitrates Directive (1991). Council Directive 91/676/EEC concerning the protection of waters against pollution. Available online at: https: //ec.europa.eu/environment/water/water-nitrates/index_en.html (accessed September 15, 2019).

Ourry, A., Mesle, S., and Boucaud, J. (1992). Effects of osmotic-stress ( $\mathrm{NaCl}$ and polyethylene-glycol) on nitrate uptake, translocation, storage and reduction in ryegrass (Lolium-perenne L). New Phytol. 120, 275-280.

Prasad, S., and Chetty, A. A. (2008). Nitrate-N determination in leafy vegetables: study of the effects of cooking and freezing. Food Chem. 106, $772-780$.

Radcliffe, S. A., Miller, A. J., and Ratcliffe, R. G. (2005). Microelectrode and $133 \mathrm{Cs}$ nuclear magnetic resonance evidence for variable cytosolic and cytoplasmic nitrate pools in maize root tips. Plant Cell Environ. 28, 1379-1387.

Raven, J. A. (2017). Chloride: essential micronutrient and multifunctional beneficial ion. J. Exp. Bot. 68, 359-367. doi: 10.1093/jxb/erw421

Ríos, J. J., Blasco, B., Cervilla, L. M., Rubio-Wilhelmi, M. M., Rosales, M. A., Sanchez-Rodriguez, E., et al. (2010). Nitrogen-use efficiency in relation to different forms and application rates of Se in lettuce plants. J. Plant Growth Regul. 29, 164-170.

Rubio-Wilhelmi, M. M., Sanchez-Rodriguez, E., Rosales, M. A., Blasco, B., Rios, J. J., Romero, L., et al. (2012). Ammonium formation and assimilation in PSARK:: IPT tobacco transgenic plants under low N. J. Plant Physiol. 169, 157-162. doi: 10.1016/j.jplph.2011.09.011

Rugini, E. (1984). In vitro-propagation of some olive (Olea europaea spp. sativa L) cultivars with different root-ability, and medium development using analytical data from developing shoots and embryos. Sci. Hort. 24, 123-134.

Ruiz, J. M., Rivero, R. M., Cervilla, L. M., Castellano, R., and Romero, L. (2006). Grafting to improve nitrogen-use efficiency traits in tobacco plants. J. Sci. Food Agr. 86, 1014-1021.

Santamaria, P., Elia, A., Serio, F., and Todaro, E. (1999). A survey of nitrate and oxalate content in fresh vegetables. J. Sci. Food Agr. 79, 1882-1888.

Schwenke, G. D., Simpfendorfer, S. R., and Collard, B. C. Y. (2015). Confirmation of chloride deficiency as the cause of leaf spotting in durum wheat grown in the Australian northern grains region. Crop Pasture Sci. 66, 122-134.

Siddiqi, M. Y., and Glass, A. D. (1981). Utilization index: a modified approach to the estimation and comparison of nutrient utilization efficiency in plants. J. Plant Nutr. 4, 289-302.

Siddiqi, M. Y., Glass, A. D., and Ruth, T. J. (1991). Studies of the uptake of nitrate in barley: III. Compartmentation of NO3-. J. Exp. Bot. 42, 1455-1463.

Siddiqi, M. Y., Glass, A. D., Ruth, T. J., and Rufty, T. W. (1990). Studies of the uptake of nitrate in barley: I. Kinetics of 13NO3- influx. Plant Physiol. 93, 1426-1432.

Sorgona, A., Abenavoli, M. A., Gringeri, P. G., and Cacco, G. (2006). A comparison of nitrogen use efficiency definitions in citrus rootstocks. Sci. Hort. 109, 389-393.

Teakle, N. L., and Tyerman, S. D. (2010). Mechanisms of $\mathrm{Cl}^{-}$transport contributing to salt tolerance. Plant Cell Environ. 33, 566-589. doi: 10.1111/j. 1365-3040.2009.02060.x

Tilman, D., Cassman, K. G., Matson, P. A., Naylor, R., and Polasky, S. (2002). Agricultural sustainability and intensive production practices. Nature 418, 671-677.

Timm, C. A., Goos, R. J., Johnson, B. E., Sobolik, F. J., and Stack, R. W. (1986). Effect of potassium fertilizers on malting barley infected with common root rot. Agron. J. 782, 197-200.

Umar, A. S., and Iqbal, M. (2007). Nitrate accumulation in plants, factors affecting the process, and human health implications: a review. Agron. Sustain. Dev. 27, 45-57.

Urrestarazu, M., Postigo, A., Salas, M., Sánchez, A., and Carrasco, G. (1998). Nitrate accumulation reduction using chloride in the nutrient solution on lettuce growing by NFT in semiarid climate conditions. J. Plant Nutr. 21, 1705-1714.

Wang, Y. Y., Hsu, P. K., and Tsay, Y. F. (2012). Uptake, allocation and signaling of nitrate. Trends Plant Sci. 17, 458-467. doi: 10.1016/j.tplants.2012. 04.006

Wege, S., Gilliham, M., and Henderson, S. W. (2017). Chloride: not simply a 'cheap osmoticum', but a beneficial plant macronutrient. J. Exp. Bot. 68, 3057-3069. doi: $10.1093 / \mathrm{jxb} / \mathrm{erx} 050$ 
Wen, Z., Tyerman, S. D., Dechorgnat, J., Ovchinnikova, E., Dhugga, K. S., and Kaiser, B. N. (2017). Maize NPF6 proteins are homologs of Arabidopsis CHL1 that are selective for both nitrate and chloride. Plant Cell 29, 2581-2596. doi: 10.1105/tpc.16.0 0724

White, P. J., and Broadley, M. R. (2001). Chloride in soils and its uptake and movement within the plant: a review. Ann. Bot. 88, 967-988. doi: 10.1016/j. tplants.2012.04.006

Whitehead, D. C. (1985). Chlorine deficiency in red-clover grown in solution culture. J. Plant Nutr. 8, 193-198.

Woodend, J. J., and Glass, A. D. M. (1993). Genotype-environment interaction and correlation between vegetative and grain production measures of potassium use-efficiency in wheat (T. aestivum L.) grown under potassium stress. Plant Soil 151, 39-44.

Xing, Y., Jiang, W., He, X., Fiaz, S., Ahmad, S., Lei, X., et al. (2019). A review of nitrogen translocation and nitrogen-use efficiency. J. Plant Nutr. 42, 2624-2641.
Xu, G., Fan, X., and Miller, A. J. (2012). Plant nitrogen assimilation and use efficiency. Annu. Rev. Plant Biol. 63, 153-182. doi: 10.1146/annurev-arplant042811-105532

Xu, G., Magen, H., Tarchitzky, J., and Kafkafi, U. (2000). Advances in chloride nutrition of plants. Adv. Agron. 68, 97-150.

Conflict of Interest: The authors declare that the research was conducted in the absence of any commercial or financial relationships that could be construed as a potential conflict of interest.

Copyright (C) 2020 Rosales, Franco-Navarro, Peinado-Torrubia, Díaz-Rueda, Álvarez and Colmenero-Flores. This is an open-access article distributed under the terms of the Creative Commons Attribution License (CC BY). The use, distribution or reproduction in other forums is permitted, provided the original author(s) and the copyright owner(s) are credited and that the original publication in this journal is cited, in accordance with accepted academic practice. No use, distribution or reproduction is permitted which does not comply with these terms. 